IZA DP No. 7095

FDI and Wages: Evidence from Firm-Level and Linked Employer-Employee Data in Hungary, 1986-2008

John S. Earle

Álmos Telegdy

Gábor Antal

December 2012 


\title{
FDI and Wages: Evidence from Firm-Level and Linked Employer-Employee Data in Hungary, 1986-2008
}

\author{
John S. Earle \\ George Mason University, CEU, IE-HAS and IZA \\ Álmos Telegdy \\ CEU, IE-HAS and IZA \\ Gábor Antal \\ CEU and IE-HAS
}

\section{Discussion Paper No. 7095 \\ December 2012}

\author{
IZA \\ P.O. Box 7240 \\ 53072 Bonn \\ Germany \\ Phone: +49-228-3894-0 \\ Fax: +49-228-3894-180 \\ E-mail: iza@iza.org
}

\begin{abstract}
Any opinions expressed here are those of the author(s) and not those of IZA. Research published in this series may include views on policy, but the institute itself takes no institutional policy positions. The IZA research network is committed to the IZA Guiding Principles of Research Integrity.

The Institute for the Study of Labor (IZA) in Bonn is a local and virtual international research center and a place of communication between science, politics and business. IZA is an independent nonprofit organization supported by Deutsche Post Foundation. The center is associated with the University of Bonn and offers a stimulating research environment through its international network, workshops and conferences, data service, project support, research visits and doctoral program. IZA engages in (i) original and internationally competitive research in all fields of labor economics, (ii) development of policy concepts, and (iii) dissemination of research results and concepts to the interested public.
\end{abstract}

IZA Discussion Papers often represent preliminary work and are circulated to encourage discussion. Citation of such a paper should account for its provisional character. A revised version may be available directly from the author. 
IZA Discussion Paper No. 7095

December 2012

\title{
ABSTRACT \\ FDI and Wages: Evidence from Firm-Level and Linked Employer-Employee Data in Hungary, 1986-2008 ${ }^{1}$
}

\begin{abstract}
We estimate the wage effects of foreign direct investment (FDI) with universal firm-level and linked employer-employee panel data containing 4,926 foreign acquisitions in Hungary. Matching on pre-acquisition data and controlling for fixed effects for firms and detailed worker groups, we find 12-28 percent effects on average wages. The wage effect mostly reverses for 983 foreign acquisitions later divested to domestic owners. We find positive effects for all worker types, occupations, and wage quantiles. The evidence implies little role for either measurement problems or residual selection, but suggests a strong cross-firm association of FDI wage premia with similar differentials in productivity.
\end{abstract}

JEL Classification: F23, F66, J31

Keywords: foreign acquisitions, FDI, earnings, wage differentials, productivity, difference-in-differences matching, employer effects, Hungary

Corresponding author:

John S. Earle

School of Public Policy

George Mason University

3351 Fairfax Drive, MS 3B1

Arlington, VA 22201

USA

E-mail: earle@gmu.edu

\footnotetext{
${ }^{1}$ We are grateful to Judith Hellerstein, Gábor Kézdi, John Pencavel, Thorsten Schank, and Jonathan Wadsworth for helpful comments; to the Data Sources Department of the IE-HAS for cleaning and harmonizing the Wage Survey data; to Márk Kovács, Anna Lovász, Mariann Rigó, and Péter Révész for conscientious data preparation; and to László Tőkés for excellent research assistance. The paper benefited from presentations at the Central European University, Bureau of Labor Statistics, Institute of Economics - Hungarian Academy of Sciences, Sabanci University, IFN Stockholm, Firms and Wages Workshop in Budapest, COST workshop in Amsterdam, Hungarian Labor Conference in Szirák (2009), CAED conferences in London (2010) and Tokyo (2009), EACES workshop in Moscow (2010), SIRE workshop at Heriot-Watt University (2011), Conference of the Hungarian Association of Economists in Budapest $(2010,2012)$, and Wesleyan University. All errors are our own.
} 


\section{Introduction}

The possibility of substantial "employer effects" in wage determination suggests that firms play a role beyond passively conveying market forces of demand and supply. Research documenting employer effects using linked employer-employee data (e.g., Groshen 1991; Abowd, Kramarz, and Margolis 1999; Hellerstein and Neumark 1999) thus opens up a number of interesting questions: What characteristics of firms are associated with high and low wages? Are the effects of these characteristics neutral across workers, or do they reflect winners and losers across different groups of employees? What factors explain the observed wage differences across firms - are they due to measurement artifacts, selection bias, unmeasured heterogeneity, or do they represent genuine differences in economic behavior?

We address these questions in this paper focusing on a firm characteristic that has been the subject of controversy in the context of both policy and research: foreign versus domestic ownership. Analysis of foreign controlling ownership (foreign direct investment or FDI), has consistently documented a positive average wage premium in the raw data (e.g., Lipsey 2002; Moran 2011). However, a crucial question is whether FDI may be selective, "cream-skimming" or "cherry-picking" the best domestic firms for acquisition and the best areas and industries for greenfield start-ups. Studies at the firm-level have sometimes addressed this problem using matching methods or fixed effects, usually finding a significant wage gap in favor of foreign ownership even after these adjustments. ${ }^{2}$ However, the firm-level data typically contain no information on individual worker wages and characteristics, thus making it impossible to control for employee composition or to estimate wage effects for different types of workers. Studies of worker-level data with information on employer ownership can address these latter issues, but they generally contain little information on firm characteristics and for their selection into ownership types. The advantages of both types of data can in principle be combined with linked employeremployee data (LEED), and the results from recent LEED studies have been mixed, sometimes implying that the causal effect of foreign ownership is small or non-existent. ${ }^{3}$ A general problem in this literature is that many databases contain few foreign acquisitions or a short time series for analysis, and analysis of worker heterogeneity is frequently limited to only two skill groups.

This paper builds on this research in a number of ways. We estimate the impact of foreign acquisitions on wages in Hungary, an economy that rapidly liberalized inward investment during the 1990s. The Hungarian case provides not only large numbers of acquisitions across most sectors of the economy, but also firm-level data and LEED that are particularly suitable for estimation. The firm-level data we study have the advantage of complete coverage and detailed financial information over a 23-year long panel (1986-2008); they include 4926 foreign acquisitions with information prior to and after acquisition, usually several years of each. The LEED are less comprehensive, based on a random sample of personnel records for about 7 percent of all Hungarian business sector employees, but they permit us to analyze the variation in wages among workers and to control for their characteristics, so that the (observable) composition of employment is held constant. The LEED contain fewer foreign acquisitions with both pre- and

\footnotetext{
${ }^{2}$ See, Conyon, Girma, Thompson, and Wright (2002) and Girma and Görg (2007) on the UK; Aitken, Harrison, and Lipsey (1996) on Mexico, Venezuela, and the US; Feliciano and Lipsey (2006) on the US; Lipsey and Sjöholm (2004) on Indonesia; and Brown, Earle, and Telegdy (2010) on Eastern Europe.

${ }^{3}$ See Almeida (2007) and Martins (2011) on Portugal; Heyman, Sjöholm, and Tingvall (2006, 2007) on Sweden; Huttunen (2007) on Finland; Andrews, Bellman, Schank, and Upward (2007) on Germany; Earle and Telegdy (2008) on Hungary; and Martins and Esteves (2008) on Brazil.
} 
post-acquisition data - 644 - but more than in most previous research, and they contain 2.5 million worker-year observations within the linked firms. Individual variables include wages, schooling, age, gender, occupation, and a dummy for recent hire. While the worker-level data do not contain a unique identifier, the available characteristics are detailed enough to enable us to follow most workers remaining with the same employer, and to estimate separation and hiring rates.

Our empirical strategies tap the richness and size of these data in several ways. Excluding greenfield FDI, we focus on acquisitions for which the pre- and post-acquisition information may help identify a foreign effect. Throughout, we exploit the full longitudinal structure of the data, rather than selecting arbitrary pre- and post-acquisition years. Following evaluation methods originally designed for training programs (Heckman, Ichimura, and Todd 1998; Blundell and Costa Dias 2000), we use detailed financial and wage history over multiple years prior to acquisition to construct control groups of non-acquired firms. By contrast, most previous studies of FDI and wages are restricted by available data to coarser-grained matching based on information only from the year of acquisition or the year just before. ${ }^{4}$ We combine matching with regression including firm fixed effects to account for time-invariant heterogeneity across firms. In some specifications, we include fixed effects for worker-types within firms, defined by interactions of gender, educational category, years of experience, and county. In others, we include workerfirm fixed effects, in order to identify the impact on wages of incumbents at the time of takeover.

Using these methods, we find consistent evidence of a positive impact of foreign acquisitions. In our preferred specifications the estimates lie in the range of 12 to 27 percent. They are smaller than both the raw foreign premium and the premium implied by simple OLS regressions, which are 45-60 percent in the full data and 30-45 percent in the matched sample, based on a Nopo (2008) decomposition, which suggests that acquired firms are positively selected on the factors for which our methods control. On the other hand, the magnitudes of the estimated FDI effects are similar to or greater than typical estimates reported for the regression-adjusted wage differentials associated with unionism, firm size, gender, race, and job displacement.

In an extension of this identification approach, we take advantage of 983 observations on Hungarian firms acquired by foreign investors but later re-divested into domestic Hungarian hands. Using these "treatment reversals," we examine the extent to which the estimated acquisition and divestment effects are symmetric - similar in magnitude but opposite in sign. While rejecting symmetry does not necessarily invalidate a causal interpretation of the estimated acquisition effect, a finding of no reversal would imply that the acquisition effects we have estimated are either coincidental or for some reason tend to persist even after the foreign owners have departed. Our symmetry test is particularly strong as it involves ownership switches within the same firm where we can control for firm and worker group fixed effects, thus removing any time-invariant, unobservable differences in firm and worker-group characteristics between acquisitions and divestments. The results from this analysis show, especially in the matched sample, that divestment largely reverses the acquisition effect. This "treatment reversal" result suggests that the foreign wage premium reflects distinctive actions or characteristics of the foreign owners, rather than the acquisition process or the nature of the target.

Do these positive average wage effects from foreign acquisition mask differences in the outcomes experienced by different types of workers, so that there may be "winners" and "losers" or different levels of "winning"? Most previous research distinguishes only two types of worker ("high" and "low" skill, frequently identified with Defining worker groups by characteristics

\footnotetext{
${ }^{4}$ In most previous studies, the length of the panel is 5 years or less, and the number of ownership switches is typically between 100 and 300. Studies with more switchers usually have few observations per firm before and after the switch.
} 
according to gender, experience, education, recent hire, occupation, and wage quantile, our results imply that FDI raises wages for all groups. Even incumbent workers are estimated to realize a significant wage gain, although smaller than our estimate for post-acquisition hires. Higher skilled workers (university-educated, high-skilled occupations, and higher wage quantile) realize larger gains, but the differences are not great, and surprisingly (at least to us), we are unable to identify any groups suffering systematic wage losses following foreign acquisition.

To the extent the data permit, we consider residual selection and measurement issues as possible explanations for the foreign wage premium. We find only very slight differences between acquired and domestic firms in worker separation and hiring rates, in firm survival rates, and in employment changes after acquisition. Moreover, the data generally show only small effects on worker composition in acquired firms, although we do observe a substantial rise in university educated employees. Concerning measurement problems, we analyze limited information on hours worked, possible under-reporting of wages, and fringe benefits to assess their potential roles in accounting for the estimated foreign effects.

Genuine foreign effects on wages may be explained by a variety of theoretical mechanisms, including shared gains from innovation or restructuring leading to improved firm performance, compensating differentials possibly associated with higher effort, and efficiency wages to reduce worker turnover or shirking. While our purpose is not to distinguish their separate contributions (although we offer some speculations based on the patterns in our results), a common theme in these mechanisms is that the wage gains from foreign acquisition should be associated with productivity improvements. We therefore also estimate productivity effects, which we find tend to be slightly larger than the size of the estimated wage effects, consistent with an interpretation that FDI yields productivity gains shared between the owners and workers. Moreover, we find a strong positive correlation across firms in the size of the productivity and wage effects in acquired firms relative to their controls, suggesting that the wage relationship is part of a genuine change in firm behavior and not purely an artifact of selection bias.

Further delving into the productivity relationship, we study heterogeneity in the wage and productivity effects of FDI across types of acquisition target, source country, and time period. We find higher wage and productivity effects when the target is state-owned, presumably because of greater possibilities for restructuring, although we also find a significant effect for private targets. Using information available a sub-sample with source country information, we find a higher effect when the source country is relatively well-developed, defined as a larger GDP per capita compared to Hungary. These results suggest that the wage effects of FDI tend to rise with the potential for productivity improvement. On the other hand, when we permit the effects to vary by time periods, we find similar FDI effects for both wages and productivity despite Hungary's development during the post-socialist transition.

The next section describes the construction of our database, the evolution of FDI in Hungary, wages, and other variables. Section 3 describes the estimation procedures, Section 4 presents the results and Section 5 concludes with a summary and suggestions for further research.

\section{Data and Context}

\section{Data Sources and Samples}

Appendix B to this paper contains a full description of the data, which we summarize only briefly here. The main source of our firm-level panel is the National Tax Administration (TA) of Hungary. These data are available annually from 1992 to 2008 for all firms engaged in doubleentry bookkeeping, and from 1986 to 1991 for a large sample (based on inclusion in the Wage 
Survey, described below). The data thus span a long period from well before the transition started until several years after the country's accession to the European Union. The TA files include the balance sheet and income statement, the proportion of share capital held by different types of owners, and basic variables such as employment, location, and industry. In addition, for a subsample of these firms, we use data from the Hungarian Ministry of Public Administration and Justice to identify the country of origin of foreign investors in order to examine differences in the wage effect of FDI associated with differences in the source country's level of development.

The source of our worker-level data is the Hungarian Wage Survey (WS), which contains personnel information for a large probability sample of workers in 1986 and 1989 and for each year from 1992 to 2008. The sampling for this survey is complex and has changed somewhat over the years, as further described in the Web Appendix B. In 1986 and 1989, workers were randomly selected within occupational-earnings groups in each firm. Since 1992, workers are included according to birthday (2 days of each month for production workers, 3 days of each month for nonproduction workers), a procedure that results in a random sample of about 6.6 percent of production workers, and 10 percent of non-production workers. To account for these different probabilities, as well as the probability of firm inclusion (which increases in firm size) we construct weights to adjust the sample to the total number of employees in the Hungarian economy. Variables in the WS data include earnings, highest level of education, gender, age, occupation, whether the worker is a new hire, and working hours in some years.

Linking the WS with the TA firm-level data creates a linked employer-employee dataset (LEED) in which we are able to follow firms through a consistent firm identifier. Workers do not have unique identifiers and thus cannot be readily followed over time, but relying on individual characteristics and on the sampling scheme based on birthdays (which of course are timeinvariant), we are able to link many of the employees who remain in the same workplace from one year to the next. Using information on these workers, who account for 37 percent of all observations and 64 percent of those which have at least two consecutive firm-year observations, we can estimate separate foreign ownership effects for incumbent workers remaining with the firm for at least one observation point post-acquisition and we can control for unobserved worker heterogeneity among these incumbents. The regressions are weighted with the probability of inclusion in the linked worker sample.

The estimation samples exclude firms in education, health care, and two-digit industries where no foreign acquisitions took place $(15,560$ cases in the firm level data with NACE Rev 1.1 codes $12,13,42,75,80,85,91,95,99)$ and those with more than two changes in majority ownership (792 cases in the firm-level data). In the LEED, we restrict attention to full-time employees only between the age of 15 and 74. After further minor decreases due to missing values, the resulting firm-level sample comprises 1.9 million firm-year observations on 377 thousand unique firms, of which 33 thousand are linked to employee information resulting in a LEED of 2.5 million worker-years. Appendix tables B1a and B1b provide detailed information on the number of non-missing observations per year and on the aggregation of sample weights to show the magnitude of total employment that our sample represents.

\section{FDI in Hungary}

In 1986, the first year in our sample, Hungary's economy was centrally planned and foreign ownership was prohibited. Some slight changes to corporate control began with gradual decentralization and increased autonomy for state-owned enterprises in the late 1980s (Szakadát, 1993), but the first foreign acquisition took place only in 1989. In the early 1990s, the freely 
elected governments liberalized constraints on foreign investment and provided tax and other preferences for foreign investors (OECD 2000). By the mid-1990s, Hungary had the highest value of FDI per capita among all post-socialist countries (World Bank 2002). The high pace of FDI continued throughout our sample period, as EU accession became increasingly assured and was finally attained in 2004.

Using a majority foreign ownership threshold for classification as FDI acquisition, the evolution of the number and employment of foreign acquired firms in the firm-level and LEED samples is presented in Figure 1.5 Expressed as a share of the total number of domestic firms plus firms that have been acquired by foreign investors, the percentage is zero in the 1980s, and it rises during the 1990s to about 3 percent in the firm-level data and to about 7 percent in the LEED of all firms. The share of foreign acquired firms in employment rises to around 15 percent in both data sets - reflecting a larger relative size both of firms in the LEED and of firms acquired through FDI.

This rapid influx of FDI provides large numbers of observations with information both before and after acquisition that we use to help identify FDI effects. As shown in Table 1, Panel A, the full data contain 4,926 foreign acquisitions, many more than those available in previous studies of FDI and wages. In the LEED the number of ownership switches is much smaller - 644 - but still larger than in most of studies in this area. The time series before and after acquisition are also long in both datasets: the average of 9-10 years is much longer than in previous studies (acquisitions by year are shown in Appendix Table B2a, and details of the numbers of observations providing identifying variation are shown in Tables B2b and B2c).

Most of these acquisitions are "single," meaning that a domestic firm simply becomes foreign-owned and does not change ownership status again. However, many are "reversals" that start domestic, are then acquired by foreign investors, and then are subsequently divested by the foreign owners so that they become domestically owned again. These firms are especially useful in an extension of our identification strategy, discussed in the next section. There are 983 and 86 such firms in the firm and the linked data, respectively. These firms also have long time series, typically observed for 11-12 years divided roughly equally between their 3 periods of domesticforeign-domestic.

Table 1 also contains, in Panel B, the analogous information on the numbers of single acquisitions and reversals in the matched sample. After applying the matching procedures described in the next section, we obtain 1,755 acquisitions in the firm-level and 475 in the LEED, of these 401 and 61 are reversals, respectively.

\section{Variable Definitions and Summary Statistics}

The definition of the wage in the firm data is total payments to workers (not including the payroll tax and non-pecuniary benefits) divided by the average number of employees over a particular year. ${ }^{6}$ Wages are deflated by yearly CPI and measured in thousands of 2008 Hungarian forints (HUF). The first row of Table 2 shows that unconditional mean wages are twice as large in acquired firms as in the always domestic enterprises.

\footnotetext{
${ }^{5}$ As described in Appendix B, we employ a majority ownership definition of FDI because the alternatives (e.g., 10 percent, sometimes employed in international statistics) would change the classification (and results) only slightly, and in a developing country like Hungary majority control likely represents the more important threshold. Moreover, the acquisitions we study nearly always involve large, discrete jumps in foreign share: 70 percent occur in firms with zero foreign share pre-acquisition, and the average post-acquisition share jumps to 92 percent (see Appendix Figure B2).

${ }^{6} \mathrm{We}$ also examine the effects of foreign ownership on costs of non-wage benefits.
} 
The worker-level data contain information on the monthly base wage, overtime pay, and regular payments other than the base wage (such as language and managerial allowances) paid in May of each year. In addition, the data include information on the previous year's irregular payments (such as end-of-year bonuses); for most workers we add 1/12 of this variable to the other wage components, but if the worker was hired during the previous calendar year, we divide by the number of months the worker spent with the company in that year. Table 3 shows that by this measure the unconditional foreign wage premium is similar in the LEED and the firm-level data.

In addition to wages, Table 2 also presents firm characteristics and Table 3 provides worker characteristics by ownership type. Measured by the value of tangible assets or by employment, firms acquired by foreign investors tend to be much larger and have higher labor productivity (value of sales over the average number of employees), compared to always domestic firms. The industrial composition of foreign and domestic firms also differs substantially. Relative to domestic firms, foreign-owned firms are more prevalent in manufacturing and less prevalent in most other sectors. Concerning worker characteristics, the share of females and university and high school graduates is higher in foreign-acquired firms, and the shares of vocational and elementary education are lower. Average years of work experience and share of workers hired in the previous year are slightly lower under foreign ownership. ${ }^{7}$

\section{Estimation Procedures}

The unconditional means discussed in the previous section suggest large differences in observable variables between domestic and foreign-acquired firms in the population of Hungarian firms as well as in the LEED sample. To try to control for other differences, both observable and unobservable, we exploit the longitudinal structure of the data as well as the rich set of worker and firm characteristics in order to estimate panel regressions with several types of fixed effects and to construct matched samples that include a set of control firms similar to those acquired by foreigners. First we describe our regression specifications, which are applied to both matched and full samples of observations, and then we discuss the details of the matching procedures.

\section{Regression methods}

The regression samples are always defined to include firms under domestic ownership and those that were formerly domestic but have been acquired by foreign investors, but the estimation methods vary with the type of data. For the firm-level data, our basic estimating equation relates average wages to ownership status and controls:

$$
\ln \left(W_{j t} / E_{j t}\right)=\delta \text { Foreign }_{j, t-1}+\lambda_{t}+\alpha_{j}+u_{j t},
$$

where $j$ indexes firms and $t$ indexes years, $\ln \left(W_{j t} / E_{j t}\right)$ is the natural logarithm of the wage bill per employee, Foreign $_{j, t-1}$ is a dummy variable that takes the value of one if the firm was controlled by foreign owners at the end of the previous year (when ownership is measured), $\delta$ is the foreign effect, the parameter of interest, $\lambda_{t}$ represents 23 year effects, $\alpha_{j}$ are firm fixed effects (FFE), and $u_{j t}$ is an error term. The $\alpha_{j}$ control for time-invariant heterogeneity of wages across firms; in some basic specifications we omit the $\alpha_{j}$ and control for industry affiliation and 7 regional establishment locations (not collinear with FFE). Firm-level regressions are weighted by employment.

This specification is non-parametric; it could be computed as a weighted average of differences between foreign acquired and domestic firms in wages demeaned by region, year, and firm. It is parsimonious in avoiding any attempt to control for time-varying covariates of

\footnotetext{
${ }^{7}$ The recent hire variable equals 1 if the worker was hired during the previous calendar year. Since the reporting date is May, this variable does not capture hires in the given year between January and April.
} 
wages and ownership; variables such as size or productivity that are sometimes included in firmlevel wage equations are potentially endogenous and represent potential channels through which ownership may affect wages. Thus, we control for their average levels with fixed effects, but do not remove the effects of changes in these variables after acquisition. ${ }^{8}$

The equivalent specification to Equation (1) using LEED can be written:

$$
\ln _{i j t}=\delta \text { Foreign }_{j, t-1}+\boldsymbol{X}_{i j t} \boldsymbol{\beta}+\lambda_{t}+\alpha_{j}+v_{i j t},
$$

where $i$ indexes workers, $j$ indexes firms and $t$ indexes time. $\ln w_{i j t}$ is the natural logarithm of individual monthly earnings, $\boldsymbol{X}_{i j t}$ is a vector of individual and job characteristics, $\lambda_{t}$ are year effects, $\alpha_{j}$ are firm fixed effects (FFE), and $v_{i j t}$ captures unobserved components of individual wages. LEED regressions are weighted to reflect the probability of inclusion in the Wage Survey and to adjust the sample to the total number of employees in the Hungarian economy.

In our specifications, $\boldsymbol{X}_{i j t}$ typically includes three educational categories (VOCATIONAL, HIGH SCHOOL, and UNIVERSITY, with ELEMENTARY - less than 9 years of schooling omitted), EXPERIENCE (potential) in level and quadratic form, a dummy variable for female employees (FEMALE), and a full set of interactions among these variables. In an additional specification, we add dummy variables for broad occupational categories and whether the worker was recently hired in the past year, to control for these aspects of workforce composition. In some specifications, we omit the $\alpha_{j}$ and control for industry affiliation and establishment location.

Unobserved heterogeneity may vary not only at the firm level, of course, but also within groups of workers in the same firm, so in another specification using the LEED we interact the firm fixed effect with narrowly defined groups of workers defined by gender, four education categories, and eight experience groups. We also distinguish workers by county (which is defined at the plant level) and the resulting grouping is interacted with firm identifiers. This specification thus allows a different intercept for each education-gender-experience-county group within each firm, adding about 400,000 worker group-firm fixed effects (WGFE) to the regressions. We also add worker fixed effects (WFE) to regressions that focus on incumbent workers, with identification coming from the 37 percent of all workers we are able to follow within employers.

In a further extension of our identification strategy, in some specifications we disaggregate Foreign $_{j, t-1}$ into two types of foreign acquisitions: (1) single acquisitions (i.e., simple transition from domestic to foreign ownership), and (2) foreign acquisitions followed later by divestment to domestic owners (i.e., domestic acquisition) after at least one year of foreign ownership (i.e., double transition: domestic-foreign and foreign-domestic). In the latter case, the foreign effect can be estimated twice: once from each transition. The specification can include firm fixed effects to account for unobserved differences in firms acquired and divested, and a comparison of the estimated effects associated with acquisition and divestment provides a "symmetry test" - an evaluation of whether any estimated foreign wage effect remains after divestment, or whether wages revert to their earlier level and thus tend to be associated with ownership type.

The detailed characteristics in the LEED enable us to estimate separate FDI effects by worker characteristics, including gender, education, experience, recent hire status, and occupation. Together with quantile regressions, these results provide information on the potential winners and losers from foreign acquisition.

Although our methods (including the matching procedures described below) are designed to minimize selection bias in the sense of correlation between the probability of foreign acquisition

\footnotetext{
${ }^{8}$ We report all standard errors permitting general within-firm correlation of residuals using Arellano's (1987) clustering method, so the standard errors are robust to both serial correlation and heteroskedasticity. See Kézdi (2004) for a detailed analysis of autocorrelation and the robust cluster estimator in panel data models.
} 
and unobserved influences on wage growth, we also look for evidence of selection effects by analyzing the impact of foreign acquisition on worker composition, hiring and separation rates, and firm exit. To examine the relationship of the FDI wage effects with productivity, we employ a specification similar to equation (1) with output as dependent variable and capital, labor, and materials added to the regressors. The effects of FDI on wages and productivity are permitted to vary with time period of acquisition, GDP per capita of the FDI source country, and state versus private ownership of the domestic target.

\section{Matching procedures}

Our description of the basic characteristics of domestically owned and foreign acquired firms showed large differences along many dimensions. To construct a control group as similar as possible to the group of acquired firms, we apply propensity score matching (Rosenbaum and Rubin, 1983). We match on firm, rather than worker, characteristics both because acquisition is a firm-level event and because this allows to use the longitudinal history of firm-level variables in the matching process. We include only those acquisitions which have observations on average wages one and two years pre-acquisition, and at least one post-acquisition. As potential controls we also use only those always domestic firms which satisfy this requirement relative to the year when we add them among controls.

Subject to these restrictions, the propensity score is obtained from estimating a probit regression on a sample including all years of firms that are always domestic and the acquisition year of acquired firms. Pooling the data produces a much larger sample size for the estimation than would year-by-year probits, and therefore we down-weight the potential controls to give equal weight in the regression to treated and potential controls. Independent variables include the logarithms of the level and square of average earnings, employment, labor productivity (value of sales over employment), capital intensity (value of tangible assets/employment) in the year before acquisition; wage and employment growth from two years before acquisition to one year before acquisition; and industry and year effects. By including pre-treatment levels and growth of wages among the regressors, we match on not only observable characteristics but unobservables as well.

The details of the results are reported in Appendix A. In general, the direction of the effects of explanatory variables is the same in the two datasets (Table A1), although none of the estimated coefficients are significant at the five percent level in the LEED, where sample size is smaller. Bigger firms with higher average wages, higher productivity and higher capital intensity are more likely to be acquired. Faster growing companies are also more often acquisition targets, while wage growth does not seem to have a significant influence on investors' decisions and the point estimate is negative in contrast with the effect of the level of wages.

Having obtained the propensity score, we enforce common support of its distribution across treated and control firms by dropping the treated (control) firms which have larger (smaller) propensity score than the largest (smallest) score obtained for control (treated) firms. On the common support we then match exactly on industry and year; within each industry-year cell we match (with replacement) each treated firm to its nearest neighbor measured by the propensity score. To check the quality of our matches, we compute normalized mean differences in the matching variables between the treated and the control groups one year before acquisition. Table A2 shows that differences are very low, none of them exceeding $0.025 .{ }^{9}$

Appendix B contains details about the distribution of matched acquisitions over time, which are fairly uniform (Table B3), and comparisons of characteristics across the matched and

\footnotetext{
${ }^{9}$ Imbens and Rubin (2010) suggest that as a rule of thumb differences below 0.25 are acceptable.
} 
full samples (Tables B4-B5). Matched companies are on average larger and more productive, pay higher wages, and are more likely to operate in manufacturing relative to the typical firm in the data. Employees in the matched LEED sample are more likely to be female and have higher education compared to those in the full LEED.

Thus, estimates for the matched sample pertain to different types of firms and employees than those in the full samples. To compare the raw foreign wage premium across the full and the matched samples, we apply a decomposition suggested by Nopo (2008) of the total differential into three components: the differential in the matched sample, the differential between matched and unmatched domestic firms, and the differential between unmatched and matched foreign-acquired firms. More formally, let $E(w \mid \varphi), E_{m}(w \mid \varphi)$ and $E_{n m}(w \mid \varphi)$ denote the mean of log real wages in the full sample, in the matched sample, and in the non-matched part of the full sample, respectively, where $\varphi$ denotes the sample: $\varphi=F$ for treated (foreign acquired) firms and $\varphi=D$ for control (always domestic) firms. Let $\gamma_{t}$ denote the share of observations in each sample that could not be matched. Then we can express mean wages in each sample as a weighted average of the mean in the matched part and of the mean in the unmatched part of the full sample. That is,

$$
E(w \mid \varphi)=\gamma_{t} E_{n m}(w \mid \varphi)+\left(1-\gamma_{t}\right) E_{m}(w \mid \varphi)=\gamma_{t}\left[E_{n m}(w \mid \varphi)-E_{m}(w \mid \varphi)\right]+E_{m}(w \mid \varphi) \text {, for } \varphi=F, D \text {. }
$$

Substituting (3) into the wage gap in the full sample, $E(w \mid F)-E(w \mid D)$, yields the following decomposition:

$$
E(w \mid F)-E(w \mid D)=\left[E_{m}(w \mid F)-E_{m}(w \mid D)\right]+\gamma_{T}\left[E_{n m}(w \mid F)-E_{m}(w \mid F)\right]+\gamma_{C}\left[E_{m}(w \mid D)-E_{n m}(w \mid D)\right],(4)
$$

where the first term in the sum represents the difference in mean wages between acquired and nonacquired firms in the matched sample, the second term shows how non-matched treated firms differ from matched treated firms (weighted by the relative frequency of non-matched observations in the treated group), and the third term gives the wage gap between matched domestic and nonmatched domestic companies (weighted by the relative frequency of non-matched observations in the control group).

To perform the decomposition we first remove year and region effects from log wages by running simple pooled OLS regressions and then we estimate (4) non-parametrically by computing weighted averages of the residuals. The results in Table 4 show that the differential in the matched sample is around eighty percent of the total gap in the firm data, and about seventy percent in the individual data. Independently of the level of aggregation, matched control firms pay approximately 20 percent higher wages than unmatched control firms, increasing the estimate in the full samples compared to that on the common support. Surprisingly, matched treated firms are of higher wages than their non-matched peers which decreases the estimated total wage premium. Because the matched and full samples represent different subpopulations, we present our findings for both of these, as well as for both the firm-level data and the LEED.

\section{Results}

We start with estimates of the average effect of FDI on wages, and then proceed to the effects by worker characteristics including demographics, skill measures, occupation, position in the wage distribution, and incumbency versus post-acquisition hiring status. We then turn to the analysis of potential measurement and selection issues, including mismeasurement in wages and possible changes in worker turnover and composition. Finally, we study the relationship of the estimated wage effects with productivity effects to help interpret our findings.

As appropriate for the purpose at hand, we present results using both the firm-level and worker-level data and both the full and matched samples in order to take advantage of the strengths of the different types of data and to examine the robustness of results. In terms of econometric 
methods, simple OLS regressions on the full samples function as benchmarks for our attempts to distinguish selection bias from causal effects, and they provide measures of average wage differentials. Our attempts to handle selection, or endogeneity of ownership, include matching and fixed effects, and it bears emphasis that differences in point estimates across specifications may result from changes in identifying variation and changes in sample composition as well as from differences in econometric approach.

\section{Estimates of the Average Effect of FDI on Wages}

Table 5 contains basic OLS estimates. The firm-level results imply a 64 log point foreign wage differential controlling only for region and year effects (to account for price differences). The estimate falls by 10 points when controls for 2-digit industries are added, thus implying some selection of higher wage industries by foreign investors. The simple average FDI effect estimated with the LEED data, shown in the lower panel, first column, implies a 47 log point differential. ${ }^{10}$

The LEED permit us to include worker characteristics and we report 3 alternative specifications: (1) controls for gender, three educational dummies (vocational, high school, university, with elementary education omitted), a quadratic function of potential experience, and interactions between these variables which are demeaned to allow the non-interacted variables show the average effect, (2) additional controls for job characteristics (a dummy variable indicating that the worker was hired during the previous year and seven broad occupational categories), (3) additional controls for 2-digit industry. Job characteristics and industry may well be jointly determined with foreign ownership, so these results should be treated with caution but they shed light on the robustness of the results, which indeed show little variation across the first three specifications. The inclusion of individual and job characteristics decreases the estimated foreign effect by only 4-5 log points. ${ }^{11}$ Including industrial controls further decreases the estimate by $10 \log$ points but it is still as large as 0.32 . The estimated wage effects of worker characteristics are always highly statistically significant and are in the usual range: the gender wage gap is around 0.2; educational wage premia (relative to elementary) are 0.05-0.10 for vocational studies, $0.17-0.35$ for high school, and $0.54-0.90$ for university; and the first year of potential experience is estimated to increase wages by $0.18-0.24$ with the profile conventionally concave. ${ }^{12}$

Table 6 adds firm fixed effects (FFE) and worker-group fixed effects (WGFE) to the regressions, where the latter use the LEED and controls from specification (2) of Table 5. Compared to the OLS results, these estimates are smaller, and the difference provides some indication of the magnitude of selection bias ("cream-skimming" or "cherry-picking") in foreign acquisitions based on these types of time-invariant heterogeneity. In all cases, however, the estimates remain sizable and statistically significant: the firm-level estimate with FFE is 0.27 , the LEED FFE estimate is 0.16 , the WGFE is 0.14 , and the results based on the matched data are 2-4 percentage points smaller. These magnitudes are in the general range or higher than typical regression-adjusted estimates reported in research on the wage effects of trade unionism (e.g., Pencavel 1991), firm size (e.g., Brown, Hamilton, and Medoff 1990), gender and race (e.g., Altonji and Blank 1999), or job displacement (e.g., Jacobson, LaLonde, and Sullivan 1993).

\footnotetext{
${ }^{10}$ The difference disappears when we use the same sample (firm-year observations) in both data sets.

${ }^{11}$ With a specification controlling only for gender, education and potential experience, but not their interactions, the results are virtually identical to those presented in the table.

${ }^{12}$ The average wage of employees with less than one year of job tenure is 8 to 12 percent less than average wages of workers with more than one year of job tenure, and the pattern of estimated coefficients on occupational dummies follows typical skill-based patterns. We do not report these estimates in the table, but they are available on request.
} 
The analysis so far did not distinguish between single acquisitions from those when a foreign takeover is followed by a divestment. In the regressions with a single foreign dummy variable we made the implicit assumption that the foreign wage effect is symmetric in both directions, but an interesting question is whether this assumption is correct. By estimating separate coefficients for firms which experienced both acquisitions and divestments during the period observed, and including firm fixed effects, we can estimate the symmetry of the foreign wage effect, eliminating any fixed differences between acquisitions and divestments.

Table 7 presents these results. Comparing the estimated acquisition effects of initial acquisitions followed by reversals with single acquisitions, the former tend to be larger in the full sample and smaller in the matched sample, but the differences are not statistically significant. The divestment effects, which measure the wage in the post-divestment domestic period relative to the pre-acquisition domestic period, in all cases provide evidence of substantial reversal of the foreign wage effect. In the full sample, the estimated coefficients imply a 37-50 percent post-divestment loss of the wage gain associated with foreign acquisition, and in the matched sample, the estimated loss ranges from 50 to 80 percent. In all three matched sample estimates, the post-divestment wage level is statistically insignificantly different from the pre-acquisition time period. These results strengthen the interpretation that the estimated foreign acquisition effects do not simply reflect the effects of acquisition (as analyzed in research on mergers and acquisitions, including Lichtenberg and Siegel 1990; McGuckin and Nguyen 2001; Siegel, Simons, and Lindstrom 2009), but instead imply systematically different behavior of foreign and domestic owners.

\section{Estimates of FDI Effects by Worker Characteristics}

While the evidence suggests significant positive effects of foreign acquisitions on average wages of workers in acquired firms, the LEED permit us to go deeper and estimate heterogeneous effects for workers with different demographic and human capital characteristics. Perhaps the positive average effects conceal variation such that some workers experience losses while others gain. If foreign ownership is associated with better technology that is complementary with human capital, then the gains may not be equally shared but rather biased towards higher skilled employees, defined by education, occupation, or position in the wage distribution. Finally, it is possible that even in the context of overall wage increases that incumbent workers, those hired preacquisition, may suffer wage losses.

To test these hypotheses, we interact the Foreign variable with worker characteristics and estimate regressions otherwise the same as equation (2). In a first set of regressions we examine standard characteristics: gender, education category, years of work experience, and recent hire status. In a second set we examine variation by occupation, in a third set we consider position in the wage distribution, and in the fourth we estimate separate effects for incumbents relative to those hired post-acquisition.

Concerning the first set, Table 8 shows that the estimated wage effect of foreign acquisition on the reference group (defined as male employees with elementary education, 10 to 20 years of work experience, and not recently hired) varies from 0.9 to 0.14 across the four specifications, and it is always statistically significantly different from zero. The estimated coefficients on the interaction terms allow us to compute estimated foreign acquisition effects for 64 different types of workers ( 2 gender categories, 4 education types, 4 experience groups, and recent hire or not recent hire). The results vary somewhat across specifications, but all of them imply that foreign ownership increases the wages for all 64 of these groups. 
The extent of the gain varies across groups, in a pattern that is broadly consistent across specifications. The biggest winners from foreign acquisition are university graduates, whose estimated gains range from 24 to 37 percent. In all specifications, there is a tendency for higher gains at higher education levels. On the other hand, returns to experience are estimated to decline under foreign ownership, but not enough to reverse the overall positive effect, even for workers with more than 30 years of experience. The estimated gender wage differential is little affected by foreign acquisition as well as the differential between recent hires and more senior workers.

Turning to differences in the foreign wage effect across occupations, Table 9 shows the results from interacting Foreign with broad occupations (approximately1-digit level). Again, the estimated effects are all positive and almost always statistically significant, and again they show evidence of skill-bias, with larger increases in higher skilled occupations.

To examine how the foreign effect varies along the wage distribution, we report quantile regression results for each $10^{\text {th }}$ quantile in Figure 2. The estimated coefficients are positive and statistically significant at each quantile, and they show a mild upward slope. While more highly paid workers indeed benefit more from foreign acquisitions than do lower earners, even the lowest wage category is estimated to receive a significant foreign wage premium.

The final heterogeneity issue concerns incumbents, defined as workers hired preacquisition, versus non-incumbents. For this analysis, as discussed in the data section above, we use longitudinal links of workers remaining with the same employer over time in order to measure whether the employee was hired before or after acquisition; in the matched sample of controls, we can also designate as "incumbents" those workers who were hired prior to the acquisition of the paired treated firm. In the matched sample estimates, we can include an incumbent dummy for employees of control firms observed both before and after the acquisition of the matched treated firm; this controls for any systematic differences between incumbents and non-incumbents that may reflect longer tenure, for instance. Using the linked information also permits us to include worker fixed effects (WFE) in the regression. Compared to our other specifications these estimates should be treated with more caution because of error in identifying incumbents and because the linked time series for most workers are quite short: to contribute at all to identification of the foreign coefficient we need at least one observation on a worker's wage before and at least one after acquisition, but nearly half of workers with pre- and post-acquisition observations have only a single observation either pre- or post-acquisition. Thus, the WFE results likely suffer from more attenuation bias than other specifications.

With these caveats, Table 10 contains the estimation results. In the full sample, the estimated effects of foreign acquisition on incumbents and non-incumbents are fairly similar in the FFE and WGFE specifications, the incumbent effect some 3 percentage points lower. The demanding WFE specification, which can be estimated only for incumbents (since non-incumbents are not observed pre- and post-acquisition), implies a smaller coefficient, but nevertheless a 6 percent positive effect. The results in this case suggest a greater non-incumbent - incumbent gap, but once again all estimates, including in the demanding WFE specification, imply positive effects of foreign ownership on wages. In the final column of Table 10, we include only workers for whom we have at least two post-acquisition observations, in an attempt to reduce the attenuation bias in the estimates, and the estimated coefficients are indeed larger by one and one-half percentage points in the full and matched samples, respectively. An alternative explanation is that workers with more post-acquisition observations have higher wages because of different employee retention patterns in foreign versus domestic enterprises. As discussed in the next sub-section, however, we are unable to find significant impacts of acquisitions on worker separations. 


\section{Measurement and Selection Issues}

One potential concern about these estimated wage effects of foreign ownership is possible measurement error in wages that is correlated with ownership. First, hours worked may differ under domestic and foreign ownership. The annual and monthly wage variables in the firm data and LEED, respectively, do not capture variation in working hours. From 1999, however, the LEED contain a variable measuring usual hours worked that we use as the dependent variable in a variant of Equation (2). The estimated Foreign effects are small and imprecisely estimated, implying that hours are little affected by foreign acquisition. ${ }^{13}$

Second, wages may be underreported for tax reasons; for instance, if underreporting is more prevalent in domestic firms the estimated foreign effect may be upward biased. While this hypothesis is inherently very difficult to test, we examine two types of evidence. The first extends Equations (1) and (2) to interact Foreign with a "cheating index" (drawn from Elek et al. 2009) representing the extent of cheating by industry. The estimates, presented in Appendix Table A4, imply that the foreign wage differential is larger in industries where underreporting is less likely, which runs counter to the hypothesis that our results are driven by underreporting of domestic firms. Second, because anecdotal information suggests that cheating frequently happens by declaring that only the minimum wage was paid, we replace the dependent variable in the LEED regression (2) with a dummy indicating whether the worker was paid very close to the minimum wage that year (defined as being paid less than 3 percent above the minimum wage). The estimates show a lower incidence of minimum wage workers in foreign employers, but the small magnitudes of the coefficient (0.038-0.066) together with the low overall incidence (about 10 percent) implies that this cannot explain the 13-25 percent foreign premium.

A third measurement issue is the possibility that the wage variables do not account for nonwage fringe benefits. In principle, it is possible that foreign owners shift compensation more towards cash and away from non-cash forms. The LEED contains no information on non-cash compensation, but the firm-level data include an accounting measure of employer costs for employee benefits. If we use the log of this variable as the dependent variable in an extension of equation (1) using firm-level data, the estimated effect of FDI on benefits is even larger than the estimated effect on wages in the full sample, and it is very similar effect to the estimated wage effect in the matched sample. ${ }^{14}$

Another potential concern in interpreting our estimates of the wage impact of foreign ownership is the possibility of residual selection on time-varying unobservables correlated with both wages and foreign acquisitions, conditional on our matching procedures and regression controls. The absence of such unobserved and unaccounted-for factors is the basic identifying assumption necessary to give a causal interpretation to our estimates. While the assumption is not directly testable, we can use the data to provide some evidence on differences in worker and firm turnover, employment levels, and worker composition by ownership type, that may help provide some indirect indications of the extent of this problem.

\footnotetext{
${ }^{13}$ Results are shown in Appendix Table A3. An alternative approach would replace monthly wages with hourly wages in our LEED regressions, but the wage variable includes several types of payments which do not vary directly with hours worked, and the very small impact of FDI on hours implies that hourly wage results would be nearly identical to the results we have presented. One potential problem with the hours regressions could be mismeasurement for white collar workers, but regressions restricted to blue collar workers yield similar results.

${ }^{14}$ The coefficients (standard errors) for the firm-level employee benefits are 0.501(0.104) and 0.236(0.066) in the full and matched samples, respectively.
} 
We first examine the impact of foreign acquisition on hiring and separation rates. Only the LEED can be used for this analysis, as the firm-level data contain no worker turnover information, and we also focus on the matched sample where pre- and post-acquisition periods can be defined for both acquisitions and controls. Hiring is defined using the recent hire variable, and because it refers to the previous calendar year, we omit the first year after acquisition from the regression. Separation is estimated on the sample of linked workers only, for whom separation can reliably be calculated. In both cases, we present both FFE and WGFE linear probability model estimates of the impact of Foreign on overall probabilities as well as a specification where we interact Foreign with the worker's wage (logged and demeaned in the regression sample), so that the coefficient on the interacted variable provides a measure of the degree to which worker turnover influences the foreign wage effects we have estimated.

The results in Table 11 show only tiny differences in the hiring and separation probabilities between acquired and domestic firms. In the FFE specification, for example, the estimated effect of Foreign is -0.00 on the hiring rate and 0.01 on the separation rate, both with larger standard errors than coefficients. The estimated coefficients differ little in the WGFE regressions. When we include the interaction with the wage, the results show no tendency for hiring or separation under foreign ownership to be higher among high-wage workers with either FFE or WGFE.

Table 12 uses the matched firm-level sample, to examine the impact of foreign acquisition on two aspects of selection at the firm level: employment changes and survival. Again, for both variables, we present estimates of the impact of Foreign on overall rates as well as a specification where we interact Foreign with the worker's wage, defined for the pre-acquisition year (to avoid mixing wage effects with any employment and exit effects of FDI. The estimates imply little difference in both employment and exit behavior between domestic and foreign firms. The one statistically significant coefficient in the table is the wage interaction for exit; at 0.007 it implies that doubling the average pre-acquisition wage of an acquired firm raises the probability of exit by 0.007. This result would be consistent with negative selection (higher wage foreign firms are less likely to survive, implying we would have estimated a larger foreign effect had they not exited), but the magnitude is too small to matter for our estimated wage effects. ${ }^{15}$

A final selection issue concerns the composition of the workforce in terms of observables. Although our LEED regressions control for workforce characteristics, sometimes in an extremely detailed way through worker group fixed effects (WGFE), changes in workforce composition may suggest that a selection mechanism is underway within firms. If unobservables and observables are highly correlated, the change in observables provides a guide to underlying changes in unobservables (e.g., Altonji, Elder, and Taber 2005). For this purpose, we use the LEED to estimate equations where the dependent variables are worker characteristics and the right hand size is the same as in Equation (1). Except for experience, the dependent variables are binary and we estimate linear probability models. We always include firm fixed effects (FFE), so that the estimated Foreign coefficients show how the workforce changes after acquisition relative to the pre-acquisition within-firm composition.

The results of this analysis, which appear in Table 13, show only small changes in composition for most worker types, including in terms of gender, experience, and most types of education. The only substantial change is in university graduates, whose probability rises 4.5

\footnotetext{
${ }^{15}$ Note that the lack of any effect of FDI on separations is inconsistent with a simple story of foreign owners protecting an unusual technology or organizational capital by raising wages to reduce quitting of workers who might otherwise share secrets with domestic competitors (e.g., Fosfuri, Motta, and Ronde 2001), although it is possible that other mechanisms offset this form of efficiency wage or that the data are not strong enough to detect it.
} 
percent in acquired firms. Relative to a baseline of about 10 percent in the total sample, this impact is further evidence of skill-biased restructuring in foreign acquired employers and it suggests that foreign acquired firms engage more intensively in selection of workers based on observable (and possibly unobservable) skill-related characteristics. However, the results cannot account for the sizable wage effects we find for all types of workers as well as for average wages.

This analysis of various aspects of worker and firm selection into foreign acquisition does not allow us to entirely rule out an important role for selection on unobservables, and indeed no non-experimental evidence ever does. For instance, even if we could follow all workers longitudinally and compute unobserved time-invariant wage components for each worker based on worker fixed effects (as in Abowd, Kramarz, and Margolis 1999), we would still have to contend with endogenous mobility and nonrandom allocation of workers across employers. Nonetheless, the available evidence is sufficient for us to entertain the possibility that the wage effects of foreign ownership we have estimated reflect genuine changes in behavior.

\section{Productivity and Wage Effects of Foreign Ownership}

What theoretical mechanisms might account for genuine foreign effects on wages? Some possibilities include shared gains from innovation or restructuring leading to improved firm performance, compensating differentials possibly associated with higher effort, and efficiency wages to reduce worker turnover or shirking. While our purpose is not to distinguish their separate contributions, a common theme in these mechanisms is that the wage gains from foreign acquisition should be associated with productivity improvements, and the largest gains should be observed where the scope for improvement is greatest. ${ }^{16}$ With this motivation, we estimate productivity effects of FDI and examine the variation of our estimated wage effects by the level of development of the source country, the time period (early versus late transition), and the ownership of the target (state versus private).

Our productivity regressions are extensions of Equation (1) with $\ln$ (real output/employment) as dependent variable. ${ }^{17}$ In one productivity specification, we also include capital and material costs per workers (thus implying a constant returns-to-scale Cobb-Douglas production function). For consistency, and we estimate identical models with the firm-level average wage as dependent variable in order to be able to compare the estimated wage and productivity effects. Table 14 reports results for two versions of these regressions, varying with whether or not the capital and material cost factors are included in each equation. When these factors are not included, in the first row, the estimated productivity effect of FDI (0.26) is slightly larger the estimated wage effect (0.25), but when the factors are included the difference is reversed (0.16 versus 0.20$)$, but in neither case is the difference statistically or economically significant.

\footnotetext{
${ }^{16}$ Lipsey (2002) and Malchow-Moller, Markusen, and Schjerning (2007) summarize the theoretical arguments, the latter by organizing alternative explanations of the wage effects of FDI organized according to the source of heterogeneity: workers, learning, or firms. Our claim is not that productivity improvement is either necessary or sufficient for wage gains under FDI, but simply that correlation of the wage and productivity effects may help strengthen the case that the measured FDI effects reflect genuine changes in behavior. A different possibility, unrelated to productivity, would be changes in the sharing of a fixed amount of rents, although the typical version of this argument would have acquisition leading to expropriation of workers' quasi-rents (e.g., Shleifer and Summers 1988; Gokhale, Groshen, and Neumark 1995), which seems moot given our finding of wage growth after acquisition.

${ }^{17}$ Previous research on productivity effects of FDI includes Aitken and Harrison (1999), Arnold and Javorcik (2009), Brown, Earle, and Telegdy (2006), Conyon et al. (2002), Benfratello and Sembenelli (2006), Harris and Robinson (2002), Haskel, Pereira, and Slaughter (2007), Javorcik (2004), Sabirianova Peter, Svejnar, and Terrell (2005), and Waldkirch and Ofosu (2010), but there has been little previous effort to examine the degree to which the wage and productivity effects of FDI tend to move together across firms or groups of firms, as we do here.
} 
These results provide evidence that foreign acquisitions raise productivity, consistent with a genuine effect on wages.

Moreover, the residuals across the two equations are highly correlated: 0.24-0.46, depending on specification. Thus, firms that raise wages more than predicted by the regression specification also tend to raise productivity more than predicted. A scatter plot of the wage and productivity residuals in acquired firms post-acquisition makes the same point graphically in Figure 3. Firms estimated to raise wages post-acquisition are twice as likely to raise productivity as not. Again, these results suggest that the FDI-wage relationship is part of a genuine change in firm behavior and not purely an artifact of selection bias.

Perhaps these productivity results also provide some clue to the larger wage effects of FDI in Hungary compared to previous research in other countries. One possibility is that Hungarian firms started the transition in the 1990s backward technologically and organizationally, far from the frontier, and thus it was relatively easy for foreign investors to raise productivity and wages. To examine this hypothesis, we estimate different wage effects by three factors: GDP per capita of the foreign investor, time period, and nature of the target. Concerning the first of these, our hypothesis is that investors from more developed countries (proxied by GDP per capita relative to Hungary's) would be likely to bring more advanced technology and organizational capital and so increase labor productivity more than those from less developed countries. ${ }^{18}$ We examine differences in wage effects of FDI by time period (the early transition period up to 1998 versus late transition thereafter) motivated by Hungary's rapid development once transition began, EU accession gradually became imminent, and was finalized in 2004. We also disaggregate target firms by ownership into state and privately owned firms with the hypothesis that state-owned firms are further from their production possibilities frontier so that FDI may have a larger effect.

Results for both the productivity and wage regressions with these specifications appear in Table 15. The interaction term between the relative GDP per capita and the foreign acquisition dummy variable is positive and significant for both wages and productivity, showing that the foreign wage effects are higher for more developed sending countries. Early and late acquisitions have similar estimated wage effects for both wages and productivity, with point estimates slightly larger in the late period, although the difference is slight and statistically insignificant at any conventional level. Finally, the estimated FDI effect is larger for state-owned targets for both variables, but again the estimated productivity effect is slightly larger than that for wages. In this case, the difference is larger in the firm-level data than in the LEED.

Taken together, the results suggest that the wage effects of FDI tend to rise with the potential for productivity improvement. Nevertheless, all the coefficients are positive and statistically significantly different from zero, implying that both types of firms and in both periods FDI led to wage increases.

\section{Conclusion}

Are there true "employer effects" on wages, or is firm behavior merely passive in conveying the market forces of product demand, production technology, and factor supply? Answering this question definitively faces daunting identification problems. Even with ideal data sets that contain long panels of linked workers and firms covering entire economies, which in principle would permit the estimation of separate fixed effects for each worker and each firm (as in Abowd, Kramarz, and Margolis 1999), the researcher has to contend with non-random switching and matching behavior of firms and workers.

\footnotetext{
${ }^{18}$ As Appendix Table B6 shows, the FDI sources are predominantly continental European economies.
} 
An alternative approach is to examine systematic differences in wages associated with firm characteristics, and with this motivation we have focused in this paper on foreign ownership. An advantage of this focus compared with some other firm (or individual) characteristics, such as size or industry (or gender or education), is that foreign versus domestic ownership is essentially a discrete variable that can switch suddenly, as is the case with the acquisitions we study in this paper. The analysis can therefore exploit changes over time, a dimension of the data unavailable to studies of time-invariant or slowly varying and continuous characteristics (e.g., Goux and Maurin 1999 on industry, and Troske 1999 on firm size).

The evidence in this paper comes from two remarkable data sets, one covering every Hungarian firm over a 23-year period, and the other a probability sample of about 8 percent of all Hungarian employees, from which we have constructed LEED. A drawback of the data is the lack of a unique worker identifier that would allow us to compute worker fixed effects based on observed job mobility, although we are able to track most workers within firms longitudinally, including those who remain employed after a foreign acquisition. Moreover, our data have the unusual advantage of coming from a country and time period with large variation in foreign ownership, our variable of interest. Data sets from other countries may have worker panels, but they generally have many fewer acquisitions with which to identify a foreign wage effect. Data quality and identifying variation are both important prerequisites for empirical evidence.

Our methods applied to these data include matching on a rich set of pre-acquisition variables including lagged wages, in order to construct a control group of non-acquired firms. We apply panel data methods identified through foreign acquisitions and find estimates lying in the range of 13 to 27 percent. These magnitudes of the estimated causal effects - while smaller than the 40-60 percent raw wage differentials, implying significant selection effects in foreign acquisitions - are similar or greater than typical estimates of other wage effects in the literature, for instance due to unions, job displacement, firm size, gender, race, or industry. Our methods also exploit the presence of "reversals" in the data - foreign acquisitions followed by later divestment back to domestic owners. The result that much of the wage gains from acquisition tend to be reversed following divestment is suggestive that foreign ownership has a causal effect on wages.

Using the LEED, our estimates can control for worker demographic and human capital characteristics including for worker group fixed effects, defined for cells on the basis of full interactions of firm-gender-age group-education group-tenure group. They also permit us to estimate effects for different types of workers, thus to examine the characteristics of "winners" and "losers" in the data. Among 64 groups defined by gender, age, education, and tenure, we do not find a single group estimated to suffer wage losses from acquisition. Similarly, we find wage gains for occupations (defined at the major group level) and for all quantiles of the wage distribution (measured at each decile). All of these groups are estimated to receive wage gains from foreign acquisition, although the gains are larger for workers with university education, and those in higher skilled occupations and higher wage quantiles. For the longitudinally linked workers in the LEED, we are also able to estimate a foreign wage effect for incumbents, which we find to be smaller than for non-incumbents but in any case positive and statistically significant despite the poorer quality (principally, shorter time series) of these data.

Do these estimated foreign effects on wages reflect true changes in behavior of firms after foreign acquisition? The reversal of the wage effect in divestitures provides particularly strong support for such a conclusion, which is reinforced by the remarkably uniform wage effect across most types of workers, suggesting a general change in firm behavior. To explore alternative interpretations, however, we consider several measurement and selection issues. The results show 
no evidence that differences in wage reporting, hours worked, or fringe benefits across foreign and domestic firms could account for the estimated foreign wage premium, and little evidence of differences in worker or firm turnover. The data do show some shift in the composition of employment towards university-educated workers at firms acquired by foreign investors, consistent with some skill bias in foreign management and restructuring, but by itself not accounting for the positive wage premia overall and for all skill groups that we have estimated.

Finally, we consider foreign ownership effects on productivity in order to assess an important correlate in most theoretical accounts of higher wages in foreign firms as well as to provide some evidence on why our findings might differ from some of those in the literature. Using matching and panel data methods applied to production functions, we find that FDI strongly raises productivity and that the magnitudes of the productivity and wage effects are similar on average and highly correlated across matched pairs of acquired and non-acquired firms. We also find that the wage and productivity effects both increase strongly in the level of development of the FDI source country and that it is greater for state-owned than private targets; on the other hand, we observe little fall in the estimated acquisition effects when we permit them to vary between early (pre-1999) and late (post-1998) periods.

Why do our results paint such a consistent picture of foreign owners changing firm behavior, while previous research - particularly using LEED - has produced inconsistent results, including some cases where foreign effects are insignificantly different from zero? The differences may lie in data, methods, and context. As we have emphasized, the size of our datain the cross-section, the time-series, and the number of switchers providing identifying variation permits us to use different methods and perhaps draw stronger inferences than would otherwise be possible. Another possibility could be that foreign owners make a bigger difference in less developed settings, and Hungary is a less-developed economy than others for which LEED have been analyzed (mostly northern European economies). With the exception of the little change in the estimated effects over the Hungarian transition, our results provide some support for a "catchup" interpretation in which the wage effect of foreign acquisitions is higher when the target firm is farther behind the productivity frontier. 


\section{References}

Abowd, John M., Francis Kramarz, and David N. Margolis, "High Wage Workers and High Wage Firms." Econometrica, Vol. 67, 251-333, 1999.

Aitken, Brian J., and Ann E. Harrison, "Do Domestic Firms Benefit from Direct Foreign Investment? Evidence from Venezuela.” American Economic Review, Vol. 89, 605-18, 1999.

Aitken, Brian J., Ann E. Harrison, and Robert E. Lipsey, "Wages and Foreign Ownership. A Comparative Study of Mexico, Venezuela and the United States." Journal of International Economics, Vol. 40(3-4), 345-371, 1996.

Altonji, Joseph G., and Rebecca M. Blank, "Race and Gender in the Labor Market." In Handbook of Labor Economics (O. Ashenfelter and D. Card, eds.), Vol. 3C, 3143-3259. Amsterdam: Elsevier, 1999.

Altonji, Joseph G., Todd E. Elder, and Christopher R. Taber, "Selection on Observed and Unobserved Variables: Assessing the Effectiveness of Catholic Schools." Journal of Political Economy, Vol. 113(1), 151-184, 2005.

Almeida, Rita, “The Labor Market Effects of Foreign Owned Firms." Journal of International Economics, Vol. 72(1), May 2007.

Andrews, Martyn, Lutz Bellmann, Thorsten Schank, and Richard Upward, "The Takeover and Selection Effects of Foreign Ownership in Germany: An Analysis Using Linked Worker-Firm Data." Research Paper 2007/2008.

Arellano, Manuel, "Computing Robust Standard Errors for Within-Groups Estimators." Oxford Bulletin of Economics and Statistics, Vol. 49(4), 431-434, November 1987.

Arnold, Jens M., and Beata .S. Javorcik, "Gifted Kids or Pushy Parents? Foreign Direct Investment and Plant Productivity in Indonesia." Journal of International Economics 79(1), 42-53, 2009.

Benfratello, Luigi, and Alessandro Sembenelli, "Foreign Ownership and Productivity: Is the Direction of Causality So Obvious?" International Journal of Industrial Organization, Vol. 24(4), 733-51, 2006.

Blundell, Richard, and Monica Costa Dias, "Evaluation Methods for Non-Experimental Data." Fiscal Studies, Vol. 21(4), 427-468, 2000.

Brown, J. David, John S. Earle, and Álmos Telegdy, "The Productivity Effects of Privatization: Longitudinal Estimates from Hungary, Romania, Russia, and Ukraine." The Journal of Political Economy, Vol. 114(1), February 2006.

Brown, J. David, John S. Earle, and Álmos Telegdy, "Employment and Wage Effects of Privatization." Economic Journal. June 2010.

Brown, Charles, James Hamilton, and James Medoff, Employers Large and Small. Cambridge: Harvard University Press, 1990.

Conyon, Martin J., Sourafel Girma, Steve Thompson, and Peter W. Wright, "The Productivity and Wage Effects of Foreign Acquisitions in the United Kingdom." The Journal of Industrial Economics, Vol. 50(1), 85-102, 2002. 
Earle, John S., and Álmos Telegdy, “Ownership and Wages: Estimating Public-Private and Foreign-Domestic Differentials with LEED from Hungary, 1986-2003." In Analysis of Firms and Employees - Qualitative and Quantitative Approaches (F. Andersson, S. Bender, J. Lane, K. Shaw, and T. von Wachter, eds.), NBER and University of Chicago, 2008.

Elek, Péter, Ágota Scharle, Bálint Szabó, and Péter András Szabó, “A bérekhez kapcsolódó adóeltitkolás Magyarországon" ("Undeclared Earnings and Tax Evasion in Hungary"). ELTE Working Papers in Public Finance No. 23, April 2009.

Feliciano, Zadia, and Robert E. Lipsey, "Foreign Ownership, Wages, and Wage Changes in U.S. Industries, 1987-92.” Contemporary Economic Policy Vol. 24(1), 74-91, 2006.

Fosfuri, Andrea, Massimo Motta, an Thomas Ronde, "Foreign Direct Investment and Spillovers Through Workers' Mobility." Journal of International Economics, Vol. 53, 205-222, 2001.

Girma, Sourafel, and Holger Görg, "Evaluating the Foreign Ownership Wage Premium Using a Difference-in-Differences Matching Approach." Journal of International Economics, Vol. 72, 97-112, 2007.

Gokhale, Jagadeesh, Erica L. Groshen, and David Neumark, "Do Hostile Takeovers Reduce Extramarginal Wage Payments?" Review of Economics and Statistics, Vol. 77(3), 470-485, August 1995.

Goux, Dominique, and Eric Maurin, "Persistence of Interindustry Wage Differentials: A Reexamination Using Matched Worker-Firm Panel Data.” Journal of Labor Economics, 17(3), 492-533, 1999.

Groshen, Erica, "Sources of Intra-Industry Wage Dispersion: How Much Do Employers Matter?" Quarterly Journal of Economics, Vol. 106, 869-884, 1991.

Harris, Richard, and Catherine Robinson, "The Effect of Foreign Acquisitions on Total Factor Productivity: Plant-Level Evidence from U.K Manufacturing, 1987-1992." Review of Economics and Statistics, Vol. 84(3), 562-568, 2002.

Haskel, Jonathan E., Sonia Pereira, and Matthew Slaughter, "Does Inward FDI Boost the Productivity of Domestic Firms?" Review of Economics and Statistics, Vol. 89(3), 482-96, 2007.

Heckman, James, J., Hidehiko Ichimura, Petra Todd, "Matching as an Econometric Evaluation Estimator.” Review of Economic Studies, Vol. 65(2), 261-294, April 1998.

Hellerstein, Judith K., and David Neumark, "Sex, Wages, and Productivity: An Empirical Analysis of Israeli Firm-Level Data." International Economic Review, Vol. 40(1), 95-123, February 1999.

Heyman, Fredrik, Fredrik Sjöholm, and Patrik Gustavsson Tingvall, “Acquisitions, Multinationals and Wage Dispersion." IFN Working Paper No. 675, 2006.

Heyman, Fredrik, Fredrik Sjöholm, and Patrik Gustavsson Tingvall, "Is there Really a Foreign Ownership Wage Premium? Evidence from Matched Employer-Employee Data." Journal of International Economics, Vol. 73, 355-376, 2007. 
Huttunen, Kristiina, "The Effect of Foreign Acquisition of Employment and Wages: Evidence from Finnish Establishments." The Review of Economics and Statistics, Vol. 89(3), 497-509, August 2007.

Imbens, Guido, and Donald B. Rubin, Causal Inference in Statistics, and in the Social and Biomedical Sciences. New York: Cambridge University Press, 2010.

Jacobson, Louis, Robert LaLonde, and Daniel Sullivan, "Earnings Losses of Displaced Workers." American Economic Review, Vol. 83(4), 685-709, November-December 1993.

Javorcik, Beata S., "Does Foreign Direct Investment Increase the Productivity of Domestic Firms? In Search of Spillovers Through Backward Linkages." American Economic Review, Vol. 94(3), 605-27, 2004.

Kézdi, Gábor, "Robust Standard Error Estimation in Fixed-Effects Panel Models.” Hungarian Statistical Review, Special English Vol. 9, 95-116, 2004.

Lichtenberg, Frank R., and Donald Siegel, "The Effect of Ownership Changes on the Employment and Wages of Central Office and Other Personnel." Journal of Law and Economics, Vol. 33(2), 383-408, 1990.

Lipsey, Robert E., "Home and Host Country Effects of FDI." NBER Working Paper No. 9293, 2002.

Lipsey, Robert E., and Fredrik Sjöholm, "Foreign Direct Investment, Education and Wages in Indonesian Manufacturing." Journal of Development Economics, Vol. 73(1), 415-422, 2004.

Martins, Pedro, "Paying More to Hire the Best? Foreign Firms, Wages and Worker Mobility." Economic Inquiry, Vol. 49(2), 349-363, 2011.

Malchow-Moller, Nikolaj, James R. Markusen, and Bertel Schjerning, "Foreign Firms, Domestic Wages.” NBER Working Paper 13001, 2007.

Martins, Pedro S., and Luiz A. Esteves, "Foreign Ownership, Employment and Wages in Brazil: Evidence from Acquisitions, Divestments and Job Movers." IZA Discussion Paper No. 3542, June 2008.

McGuckin, Robert H., and Sang V. Nguyen, "The Impact of Ownership Changes: A View from Labor Markets." International Journal of Industrial Organization, Vol. 19(5), 739-762, 2001.

Moran, Theodore H., Foreign Direct Investment and Development: Launching a Second Generation of Policy Research. Washington, DC: Peterson Institute for International Economics, 2011.

Ñopo, Hugo, "Matching as a Tool to Decompose Wage Gaps." Review of Economics and Statistics, Vol. 90(2), 290-299, May 2008.

Organization for Economic Co-Operation and Development (OECD), OECD Reviews of Foreign Direct Investment: Hungary. Paris: OECD.

Pencavel, John, Labor Markets under Trade Unionism: Employment, Wages, and Hours. Cambridge, MA: Basil Blackwell, 1991.

Rosenbaum, Paul R., and Donald B. Rubin, "The Central Role of the Propensity Score in Observational Studies for Causal Effects.” Biometrika, Vol. 70(1), 41-55, 1983. 
Sabirianova Peter, Klara, Jan Svejnar and Katherine Terrell. "Distance to the Efficiency Frontier and FDI Spillovers." Journal of the European Economic Association, Papers and Proceedings Vol. 3(2-3), 576-586, 2005.

Shleifer, Andrei and Larry H. Summers, 'Breach of trust in hostile takeovers', in (A. Auerbach, ed.), Corporate Takeovers: Causes and Consequences, pp. 33-56, Chicago: University of Chicago Press, 1988.

Siegel, Donald S., Kenneth L. Simons, and Tomas Lindstrom, "Ownership Change, Productivity, and Human Capital: New Evidence from Matched Employer-Employee Data." In Producer Dynamics: New Evidence from Micro Data (Tim Dunne, Brad Jenson, and Mark J. Roberts, eds). Chicago: University of Chicago Press, 2009.

Szakadát, László (1993), 'Property Rights in a Socialist Economy: the Case of Hungary’, in John Earle, Roman Frydman, and Andzrej Rapaczynski (eds), Privatization in the Transition to a Market Economy. Studies of Preconditions and Policies in Eastern Europe. London: Pinter Publishers.

Troske, Kenneth R., "Evidence on the Employer Size-Wage Premium from Worker-Establishment Matched Data." Review of Economics and Statistics, Vol. 81(1), 15-26, 1999.

Waldkirch, Andreas, and Andra Ofosu, "Foreign Presence, Spillovers, and Productivity: Evidence from Ghana." World Development, Vol. 38(8), 1114-1126, 2010.

World Bank, Transition, The First Ten Years: Analysis and Lessons for Eastern Europe and the Former Soviet Union, World Bank, 2002. 
Figures and Tables

\section{Figure 1: Evolution of the Share of Foreign Acquisitions, Firm-Level Data and LEED}

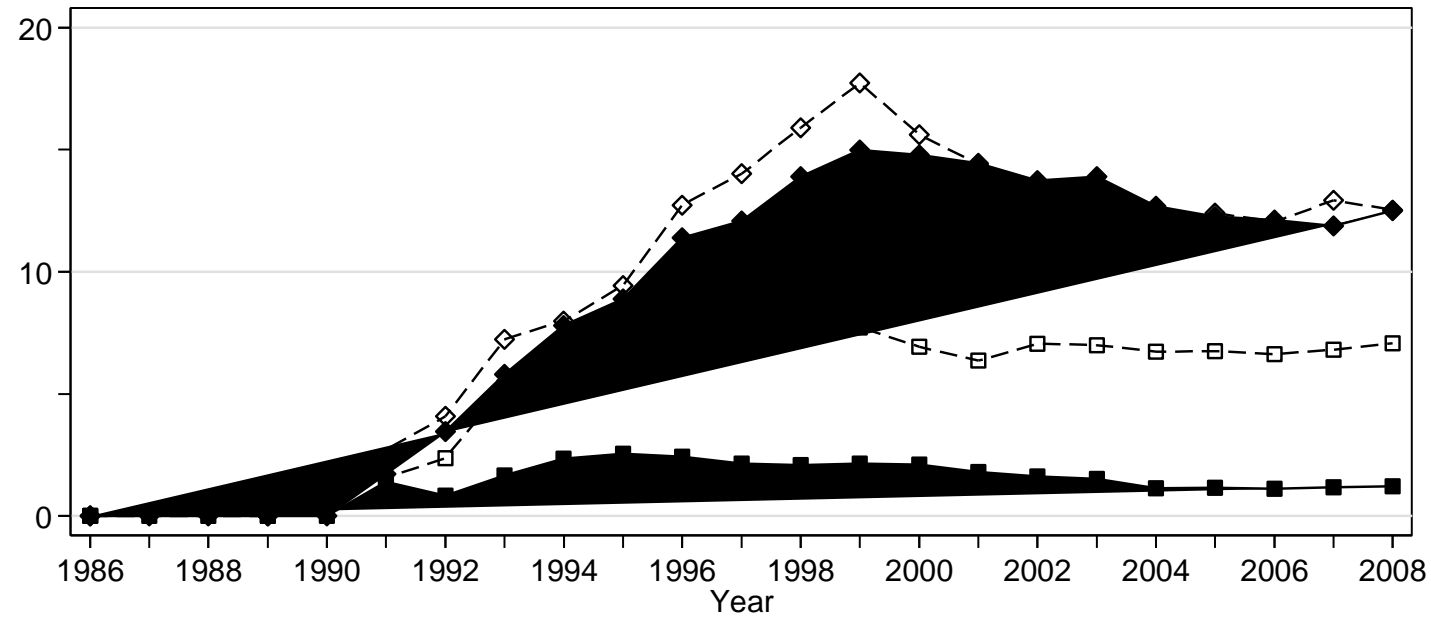

Foreign share in total employment

$\rightarrow$ Percent of foreign firms in firm-level sample

$-\diamond$ - Percent of observed workers employed by foreign firms in LEED

一 - Percent of foreign firms in LEED

Notes: $\mathrm{N}=2,475,478$ worker-years for the LEED sample and 1,881,267 firm-years for the firms sample. Sample consists of domestic firms and previously domestic firms that have been acquired by a foreign owner. Percent foreign firms = percent of firms majority foreign owned. Foreign share in total employment $=$ percentage of employees employed by majority-foreign owned firms. LEED = Linked Employer-Employee Data. 
Figure 2: The Effect of Foreign Ownership on Wages by Quantile

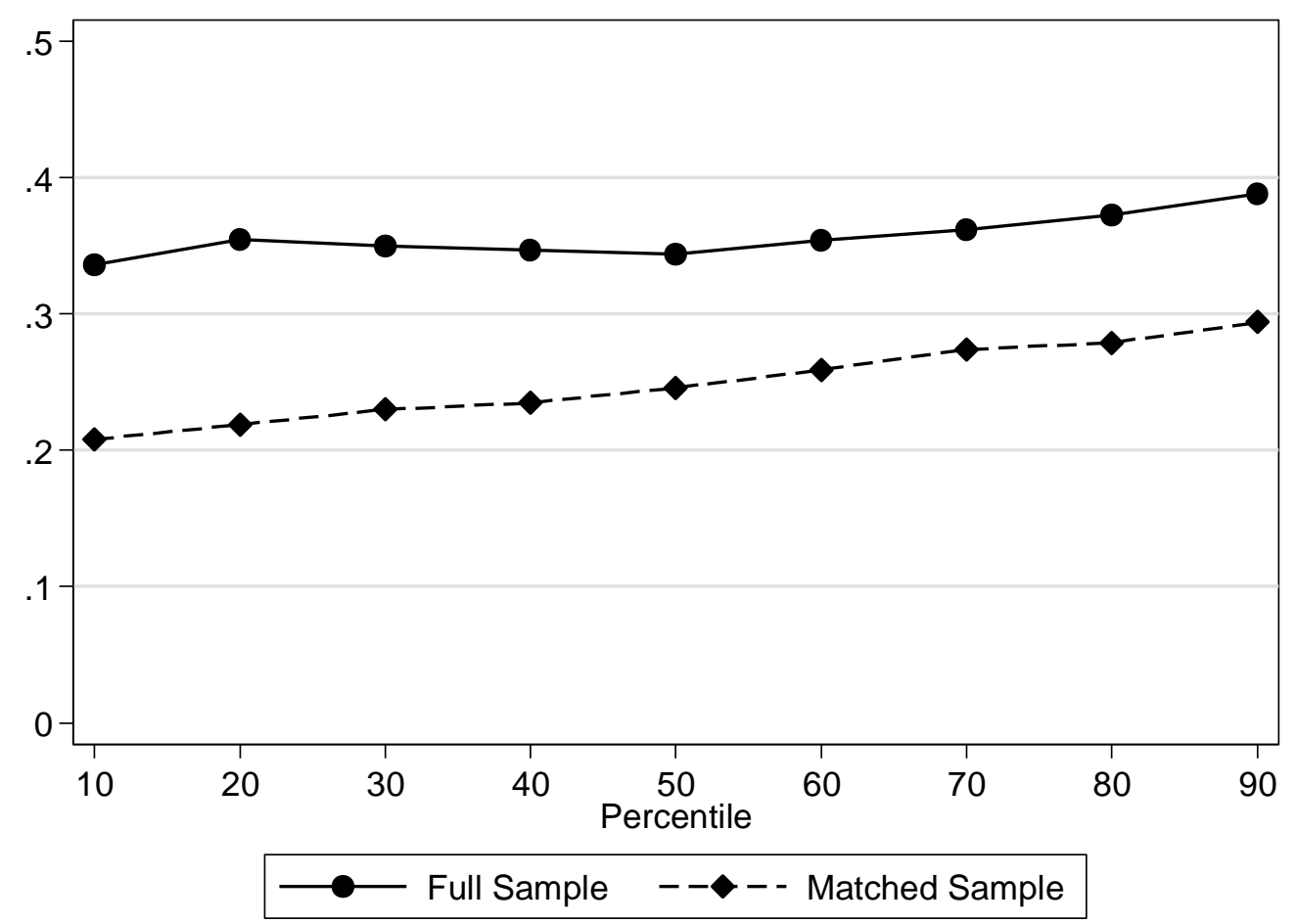

Notes: $\mathrm{N}=2,475,478$ worker-years for the full LEED and 395,053 for the matched LEED sample. Regression coefficients on foreign acquisition from quantile regressions that control for region, year and industry effects, and for post-divestment domestic period of acquired firms that are resold to domestic owners. All estimated effects are statistically significant at the 1 percent level. 
Figure 3: Scatter Plot of Wage and Productivity Residuals (Matched Sample, Post-Acquisition Years)

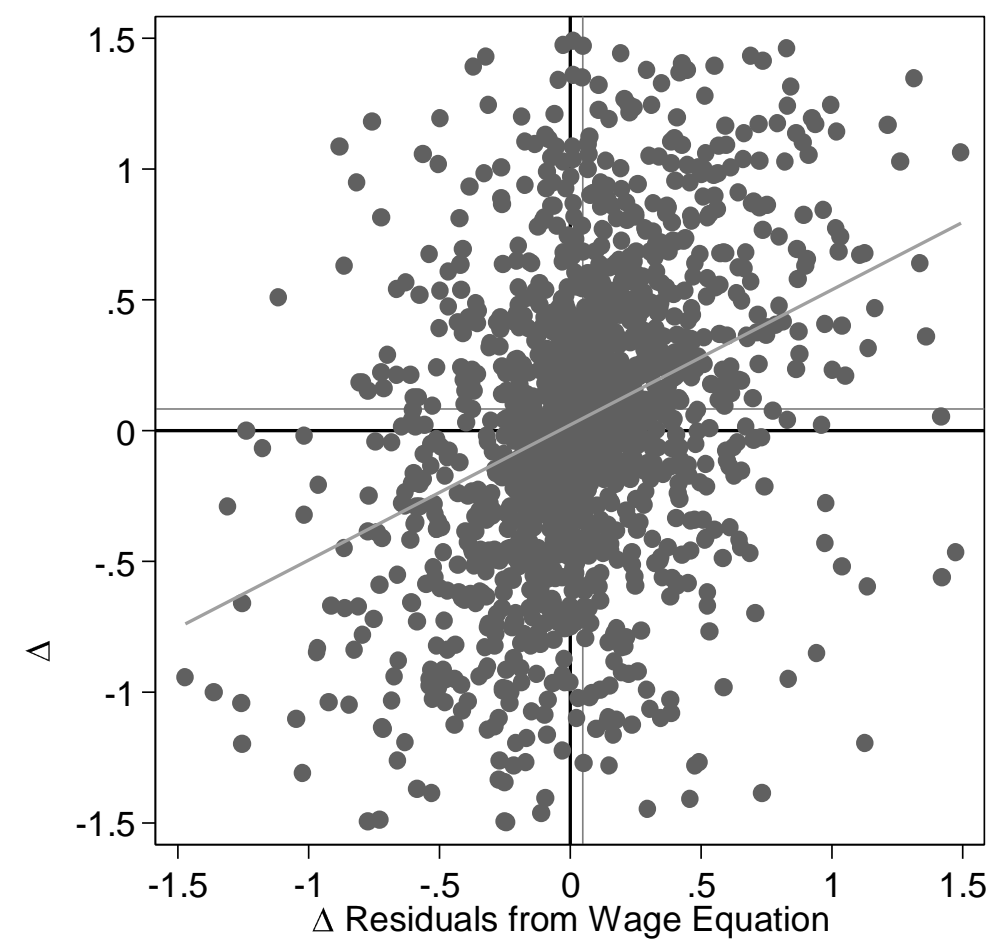

Notes: $\mathrm{N}=1,371$ matched firm-pairs. The dots represent the postacquisition difference $(\Delta)$ within matched pairs (acquired minus nonacquired firms) of the mean post-acquisition residuals from regressions with $\log$ (wage) and $\log$ (labor productivity) as dependent variables, controlling for year-industry interactions. The mean value of productivity differences $=0.084$; mean value of wage differences $=0.050$. The regression line on the graph (with SEs in parentheses) is the following: $\Delta($ mean residual wage $)=0.017(0.011)+0.425 * *(0.036) \Delta($ mean residual productivity). 210 observations where $\operatorname{abs}(\Delta$ (residuals $))>1.5$ are dropped from the graph. 
Table 1: Number of Observations on Foreign Acquisitions with Preand Post-Treatment Wage Information - Full and Matched Samples

Data Type

\begin{tabular}{|c|c|c|}
\hline & \\
\hline & Firm-Level & LEED \\
\hline \multicolumn{3}{|c|}{ Panel A: Full Sample } \\
\hline Total Number of Acquisitions & 4,926 & 644 \\
\hline Single Acquisitions: Domestic-Foreign & 3,943 & 558 \\
\hline Reversals: Domestic-Foreign-Domestic & 983 & 86 \\
\hline \multicolumn{3}{|c|}{ Panel B: Matched Sample } \\
\hline Total Number of Acquisitions & 1,755 & 475 \\
\hline Single Acquisitions: Domestic-Foreign & 1,354 & 414 \\
\hline Reversals: Domestic-Foreign-Domestic & 401 & 61 \\
\hline \multicolumn{3}{|c|}{$\begin{array}{l}\text { Notes: The table shows the numbers of firms acquired by foreign investors either as a } \\
\text { "single acquisition," where only one ownership change (from domestic to foreigr } \\
\text { ownership) is observed, or as "reversals," where a foreign acquisition is later followed by a } \\
\text { divestment from foreign to domestic owners; in both cases, only firms with pre- and post } \\
\text { change wage information are included. For acquisitions by year, see Table A2a, and for } \\
\text { total number of switches, see Tables A2b and A2c. Definition of foreign ownership: > 50\% } \\
\text { foreign-owned. }\end{array}$} \\
\hline
\end{tabular}




\section{Table 2: Firm Characteristics by Ownership - Firm-Level Data and LEED}

\begin{tabular}{|c|c|c|c|c|}
\hline & \multicolumn{2}{|c|}{ Firm-Level Data } & \multicolumn{2}{|c|}{ LEED } \\
\hline & Domestic & Foreign & Domestic & Foreign \\
\hline Average Wage & $\begin{array}{r}1,027.1 \\
(1,689.4)\end{array}$ & $\begin{array}{r}2,213.5 \\
(2,468.9)\end{array}$ & $\begin{array}{r}1,455.5 \\
(1,451.4)\end{array}$ & $\begin{array}{r}2,632.9 \\
(1,703.7)\end{array}$ \\
\hline Tangible Assets & $\begin{array}{r}162.5 \\
(6,319.8)\end{array}$ & $\begin{array}{r}2,146.7 \\
(21,513.2)\end{array}$ & $\begin{array}{r}1,365.0 \\
(20,513.4)\end{array}$ & $\begin{array}{r}9,553.1 \\
(50,248.3)\end{array}$ \\
\hline Employment & $\begin{array}{r}22.4 \\
(361.0)\end{array}$ & $\begin{array}{r}129.9 \\
(622.0)\end{array}$ & $\begin{array}{r}167.3 \\
(1,134.8)\end{array}$ & $\begin{array}{r}524.2 \\
(1,196.0)\end{array}$ \\
\hline Labor Productivity & $\begin{array}{r}22.8 \\
(178.3)\end{array}$ & $\begin{array}{r}51.3 \\
(310.0)\end{array}$ & $\begin{array}{r}21.8 \\
(309.6)\end{array}$ & $\begin{array}{r}35.4 \\
(68.4)\end{array}$ \\
\hline $\mathrm{N}$ (firm-years) & $1,857,288$ & 23,968 & 119,285 & 3,657 \\
\hline \multicolumn{5}{|l|}{ Industry in $2000(\%)$} \\
\hline Agriculture & 5.0 & 2.6 & 13.3 & 3.6 \\
\hline Mining \& utilities & 0.6 & 1.8 & 2.5 & 4.6 \\
\hline Manufacturing & 17.3 & 30.1 & 32.4 & 59.4 \\
\hline Construction & 10.1 & 3.2 & 11.2 & 3.6 \\
\hline Trade \& repair & 31.2 & 35.6 & 19.0 & 10.9 \\
\hline FIRE & 5.3 & 5.5 & 4.8 & 5.0 \\
\hline Business services & 19.3 & 10.6 & 7.8 & 6.3 \\
\hline Other services & 11.2 & 10.7 & 9.0 & 6.6 \\
\hline $\mathrm{N}$ (firms) & 91,429 & 1,659 & 8,458 & 303 \\
\hline \multicolumn{5}{|c|}{$\begin{array}{l}\text { Notes: Unweighted unconditional means and standard deviations. Average wage computed as annual wage bill } \\
\text { divided by employment and measured in thousands of } 2008 \text { HUF, tangible assets and labor productivity in millions } \\
\text { of } 2008 \text { HUF, all deflated by CPI. Standard deviations in parentheses for continuous variables. Industrial } \\
\text { distribution measured as percentages within ownership type. Definition of industries follows NACE Rev. 1.1. } \\
\text { Agriculture includes hunting, fishing, and forestry. FIRE includes finance, insurance, and real estate. Business } \\
\text { services include renting of equipment, computer and related activities, research, and other business activities. Other } \\
\text { services cover hotels and restaurants, transport and communications, and other community, social and personal } \\
\text { services. }\end{array}$} \\
\hline
\end{tabular}




\section{Table 3: Individual Characteristics by Ownership - LEED}

\begin{tabular}{lcc}
\hline & Domestic & Foreign \\
\hline Monthly Earnings & 137.3 & 240.3 \\
$(2008$ HUF, 1000s) & $(120.8)$ & $(250.6)$ \\
Female (\%) & 38.1 & 42.6 \\
Education (\%) & & \\
Elementary & 27.1 & 16.5 \\
Vocational & 33.9 & 28.4 \\
High school & 30.2 & 36.4 \\
University & 8.8 & 18.7 \\
Experience (years) & 22.7 & 21.5 \\
& $(11.0)$ & $(10.8)$ \\
Recent Hire (\%) & 11.2 & 10.0 \\
Occupation (\%) & & \\
Elementary Occupations & 10.1 & 4.7 \\
Skilled Manual Workers & 46.8 & 45.6 \\
Service Workers & 10.3 & 7.1 \\
Clerks & 7.5 & 6.2 \\
Associate Professionals & 12.7 & 18.5 \\
Professionals & 4.1 & 8.9 \\
Managers & 8.6 & 9.0 \\
\hline N (worker-years) & $2,339,534$ & 135,944 \\
\hline
\end{tabular}

Notes: Weighted unconditional means and standard deviations. Earnings measured in thousands of 2008 HUF, deflated by CPI. Female, education, recent hire and occupation measured as percentages of total workforce by ownership type. Standard deviations in parentheses. The definition of occupations follows ISCO-88 where Elementary Occupations, Service Workers, Clerks, Associate Professionals, Professionals and Managers coincide with the corresponding major groups; while Skilled Manual Workers cover Skilled agricultural and fishery workers, Craft and related trades workers and Plant and machine operators and assemblers. 
Table 4: Decomposition of Wage Differentials between Foreign Acquisitions and Domestic Firms

\begin{tabular}{|c|c|c|}
\hline & \multicolumn{2}{|c|}{ Data Type } \\
\hline & Firm-Level & LEED \\
\hline $\begin{array}{l}\text { Total mean wage differential: } \\
\text { Foreign - Domestic }\end{array}$ & 0.583 & 0.442 \\
\hline Differential in Matched Sample & 0.485 & 0.309 \\
\hline \multicolumn{3}{|l|}{ Differential between: } \\
\hline Non-Matched and Matched Treated & -0.111 & -0.055 \\
\hline Matched and Non-Matched Control & 0.210 & 0.189 \\
\hline $\mathrm{N}$ & $1,881,267$ & $2,475,478$ \\
\hline \multicolumn{3}{|c|}{$\begin{array}{l}\text { Notes: Estimates of Equation (4), a non-parametric decomposition of the foreign- } \\
\text { domestic wage gap in the full sample (following Nopo 2008). Differentials are based } \\
\text { on weighted averages of residuals from pooled OLS regressions of log wages on region } \\
\text { and year effects. Difference between non-matched and matched treated firms is } \\
\text { weighted by the share of non-matched treated firms in the universe of treated firms. } \\
\text { Difference between matched and non-matched control firms is weighted by the share of } \\
\text { non-matched control firms in the universe of control firms. All results are weighted by } \\
\text { sample weights. } \mathrm{N} \text { = firm-years in the firm-level data and worker-years in the LEED. }\end{array}$} \\
\hline
\end{tabular}




\section{Table 5: The Effect of Foreign Acquisition on Wages - OLS Estimates with Full Samples}

(1)
(2)

(3)

\begin{tabular}{|c|c|c|c|c|}
\hline \multicolumn{5}{|l|}{ Firm-Level Data } \\
\hline Foreign & $\begin{array}{l}0.639 * * \\
(0.042)\end{array}$ & - & - & $\begin{array}{l}0.536 * * \\
(0.025)\end{array}$ \\
\hline Industry effects & No & - & - & Yes \\
\hline $\mathrm{R}^{2}$ & 0.162 & - & - & 0.307 \\
\hline \multicolumn{5}{|l|}{ LEED Sample } \\
\hline Foreign & $\begin{array}{l}0.474 * * \\
(0.040)\end{array}$ & $\begin{array}{l}0.430 * * \\
(0.026)\end{array}$ & $\begin{array}{l}0.419 * * \\
(0.026)\end{array}$ & $\begin{array}{l}0.321 * * \\
(0.021)\end{array}$ \\
\hline Female & - & $\begin{array}{c}-0.215^{* *} \\
(0.007)\end{array}$ & $\begin{array}{l}-0.196 * * \\
(0.007)\end{array}$ & $\begin{array}{l}-0.174 * * \\
(0.004)\end{array}$ \\
\hline Vocational & - & $\begin{array}{l}0.098 * * \\
(0.005)\end{array}$ & $\begin{array}{l}0.051 * * \\
(0.005)\end{array}$ & $\begin{array}{l}0.060 * * \\
(0.004)\end{array}$ \\
\hline High school & - & $\begin{array}{l}0.350 * * \\
(0.007)\end{array}$ & $\begin{array}{l}0.202 * * \\
(0.007)\end{array}$ & $\begin{array}{l}0.170 * * \\
(0.005)\end{array}$ \\
\hline University & - & $\begin{array}{l}0.895 * * \\
(0.014)\end{array}$ & $\begin{array}{l}0.582 * * \\
(0.014)\end{array}$ & $\begin{array}{l}0.538 * * \\
(0.009)\end{array}$ \\
\hline Experience & - & $\begin{array}{l}0.024 * * \\
(0.001)\end{array}$ & $\begin{array}{c}0.019 * * \\
(0.001)\end{array}$ & $\begin{array}{l}0.018 * * \\
(0.001)\end{array}$ \\
\hline Experience $^{2} / 100$ & - & $\begin{array}{c}-0.034 * * \\
(0.001)\end{array}$ & $\begin{array}{l}-0.027 * * \\
(0.001)\end{array}$ & $\begin{array}{l}-0.024 * * \\
(0.001)\end{array}$ \\
\hline Interactions of characteristics & No & Yes & Yes & Yes \\
\hline Job characteristics & No & No & Yes & Yes \\
\hline Industry effects & No & No & No & Yes \\
\hline $\mathrm{R}^{2}$ & 0.125 & 0.360 & 0.406 & 0.464 \\
\hline
\end{tabular}

Notes: Estimates of Equations (1) and (2) without firm fixed effects or matching. Dependent variable $=$ $\ln$ (real wagebill/employment) in firm-level data and $\ln$ (real gross earnings) in LEED. Foreign $=1$ if the firm is majority foreign owned in $t-1$. All equations include year, region, and divestment period effects. Columns (2)-(4) add full interactions between gender, education, and experience. Columns (3)-(4) add dummy variables for workers hired in the previous calendar year and for seven broad occupational groups. Industry effects in column (4) are two-digit NACE industries. Sample includes firms always under domestic ownership and foreign-owned firms that were previously domestic (i.e., acquisitions). $\mathrm{N}=$ 1,881,267 firm-years for firm-level data and 2,475,478 worker-years for LEED. Standard errors (corrected for firm clustering) are shown in parentheses. $* *=$ significant at 0.01 . 


\section{Table 6: The Effect of Foreign Acquisition on Wages - Estimates with Fixed Effects and Matching}

\begin{tabular}{|c|c|c|c|}
\hline & \multirow{2}{*}{$\begin{array}{c}\text { Firm-Level } \\
\text { FFE }\end{array}$} & \multicolumn{2}{|c|}{ LEED } \\
\hline & & FFE & WGFE \\
\hline \multicolumn{4}{|l|}{ Full Sample } \\
\hline Foreign & $\begin{array}{l}0.286 * * \\
(0.027)\end{array}$ & $\begin{array}{l}0.177 * * \\
(0.019)\end{array}$ & $\begin{array}{l}0.148 * * \\
(0.021)\end{array}$ \\
\hline $\mathrm{R}^{2}$-within & 0.251 & 0.339 & 0.097 \\
\hline $\mathrm{N}$ & $1,881,267$ & $2,475,478$ & $2,475,478$ \\
\hline \multicolumn{4}{|c|}{ Matched Sample } \\
\hline Foreign & $\begin{array}{l}0.248 * * \\
(0.029) \\
\end{array}$ & $\begin{array}{l}0.130 * * \\
(0.024)\end{array}$ & $\begin{array}{c}0.128^{* *} \\
(0.030)\end{array}$ \\
\hline $\mathrm{R}^{2}$-within & 0.403 & 0.433 & 0.103 \\
\hline $\mathrm{N}$ & 44,406 & 395,053 & 395,053 \\
\hline \multicolumn{4}{|c|}{$\begin{array}{l}\text { Notes: Estimates of Equations }(1) \text { and }(2) \text {. Dependent variable }=\ln (\text { real wage } \\
\text { costs/employment) in firm-level data and } \ln (\text { real gross earnings) in LEED. Foreign }=1 \text { if the } \\
\text { firm is majority foreign owned in } t-1 \text {. FFE = firm fixed effect; WGFE = worker-group fixed } \\
\text { effects, based on interactions of gender, experience group, education group, county, and firm. } \\
\text { All regressions include divestment period, year, and region effects (regions pertain to } \\
\text { establishments so are not collinear with FFE). The FFE specification with the LEED also } \\
\text { includes gender, education, experience, and their interactions, as in column }(2) \text { of Table } 5 . \mathrm{N}= \\
\text { firm-years in firm-level data, worker-years in LEED. } * *=\text { significant at } 0.01 \text {. }\end{array}$} \\
\hline
\end{tabular}




\section{Table 7: Estimated FDI Effects on Wages for Single Acquisitions and Reversals - Firm-Level Data and LEED}

\begin{tabular}{|c|c|c|c|}
\hline & \multirow{2}{*}{$\begin{array}{c}\text { Firm-Level } \\
\text { FFE }\end{array}$} & \multicolumn{2}{|c|}{ LEED } \\
\hline & & FFE & WGFE \\
\hline \multicolumn{4}{|l|}{ Full Sample } \\
\hline \multicolumn{4}{|c|}{ Single Acquisitions (Domestic-Foreign) } \\
\hline Foreign & $\begin{array}{l}0.282 * * \\
(0.031)\end{array}$ & $\begin{array}{l}0.169 * * \\
(0.020)\end{array}$ & $\begin{array}{c}0.136 * * \\
(0.022) \\
\end{array}$ \\
\hline \multicolumn{4}{|c|}{ Reversals (Domestic-Foreign-Domestic) } \\
\hline Foreign & $\begin{array}{l}0.303 * * \\
(0.045)\end{array}$ & $\begin{array}{l}0.216^{* *} \\
(0.031)\end{array}$ & $\begin{array}{l}0.202 * * \\
(0.031)\end{array}$ \\
\hline Divestment & $\begin{array}{l}0.174 * * \\
(0.062)\end{array}$ & $\begin{array}{l}0.125^{* *} \\
(0.036)\end{array}$ & $\begin{array}{c}0.125 * * \\
(0.036)\end{array}$ \\
\hline $\mathrm{R}^{2}$-within & 0.251 & 0.340 & 0.097 \\
\hline $\mathrm{N}$ & $1,881,267$ & $2,475,478$ & $2,475,478$ \\
\hline \multicolumn{4}{|l|}{ Matched Sample } \\
\hline \multicolumn{4}{|c|}{ Single Acquisitions (Domestic-Foreign) } \\
\hline Foreign & $\begin{array}{l}0.253 * * \\
(0.031) \\
\end{array}$ & $\begin{array}{l}0.132 * * \\
(0.025)\end{array}$ & $\begin{array}{c}0.127 * * \\
(0.032)\end{array}$ \\
\hline \multicolumn{4}{|c|}{ Reversals (Domestic-Foreign-Domestic) } \\
\hline Foreign & $\begin{array}{l}0.216^{* *} \\
(0.056)\end{array}$ & $\begin{array}{l}0.111 * * \\
(0.027)\end{array}$ & $\begin{array}{l}0.135 * * \\
(0.030)\end{array}$ \\
\hline Divestment & $\begin{array}{c}0.079 \\
(0.058)\end{array}$ & $\begin{array}{c}0.021 \\
(0.044)\end{array}$ & $\begin{array}{c}0.070 \\
(0.057)\end{array}$ \\
\hline $\mathrm{R}^{2}$-within & 0.403 & 0.433 & 0.103 \\
\hline $\mathrm{N}$ & 44,406 & 395,053 & 395,053 \\
\hline
\end{tabular}

Notes: Foreign $=1$ if the firm is majority foreign owned in $t$ - 1 . Divestment $=1$ if the firm was majority domestic in $t-1$ but had been majority foreign in a prior year and majority domestic still earlier. The Divestment effect is measured relative to the first domestic period; i.e., for firms previously acquired by foreign and later divested to domestic owners, it measures the post-divestment wage differential relative to the pre-acquisition period. $\mathrm{FFE}=$ firm fixed effect; WGFE = worker-group fixed effects, based on interactions of gender, experience group, education group, county, and firm. All regressions include year and region effects (the latter pertain to establishments so are not collinear with FFE). The FFE specification with the LEED also includes gender, education, experience, and their interactions, as in column (2) of Table 5. $\mathrm{N}=$ firm-years in firm-level data, worker-years in LEED. $* *=$ significant at 0.01 . 
Table 8: Estimated FDI Effects on Wages by Worker Characteristics - Gender, Education, Experience, and Recent Hire

\begin{tabular}{|c|c|c|c|c|}
\hline & \multicolumn{2}{|c|}{ Full Sample } & \multicolumn{2}{|c|}{ Matched Sample } \\
\hline & FFE & WGFE & FFE & WGFE \\
\hline $\begin{array}{l}\text { Foreign Effect for } \\
\text { Reference Group }\end{array}$ & $\begin{array}{l}0.129 * * \\
(0.022)\end{array}$ & $\begin{array}{l}0.139 * * \\
(0.034)\end{array}$ & $\begin{array}{l}0.116 * * \\
(0.035)\end{array}$ & $\begin{array}{c}0.087 * \\
(0.035)\end{array}$ \\
\hline \multicolumn{5}{|l|}{ Foreign interactions with: } \\
\hline Female & $\begin{array}{l}-0.014 \\
(0.012)\end{array}$ & $\begin{array}{c}0.021 \\
(0.017)\end{array}$ & $\begin{array}{l}-0.017 \\
(0.020)\end{array}$ & $\begin{array}{c}0.019 \\
(0.018)\end{array}$ \\
\hline Vocational & $\begin{array}{c}0.019 \\
(0.011)\end{array}$ & $\begin{array}{l}-0.004 \\
(0.017)\end{array}$ & $\begin{array}{c}0.017 \\
(0.014)\end{array}$ & $\begin{array}{c}0.017 \\
(0.017)\end{array}$ \\
\hline High school & $\begin{array}{l}0.046^{* *} \\
(0.013)\end{array}$ & $\begin{array}{c}0.026 \\
(0.027)\end{array}$ & $\begin{array}{l}0.048 * * \\
(0.015)\end{array}$ & $\begin{array}{l}0.065^{* *} \\
(0.019)\end{array}$ \\
\hline University & $\begin{array}{l}0.239 * * \\
(0.033)\end{array}$ & $\begin{array}{l}0.119 * * \\
(0.041)\end{array}$ & $\begin{array}{l}0.118 * * \\
(0.038)\end{array}$ & $\begin{array}{l}0.168 * * \\
(0.028)\end{array}$ \\
\hline Experience: $0-10$ years & $\begin{array}{l}-0.033 * * \\
(0.009)\end{array}$ & $\begin{array}{l}-0.012 \\
(0.014)\end{array}$ & $\begin{array}{l}-0.017 \\
(0.012)\end{array}$ & $\begin{array}{l}-0.012 \\
(0.017)\end{array}$ \\
\hline Experience: $21-30$ years & $\begin{array}{l}-0.013 \\
(0.008)\end{array}$ & $\begin{array}{l}-0.042 * * \\
(0.010)\end{array}$ & $\begin{array}{l}-0.038 * * \\
(0.011)\end{array}$ & $\begin{array}{l}-0.041 * * \\
(0.013)\end{array}$ \\
\hline Experience: $30+$ years & $\begin{array}{l}-0.010 \\
(0.010)\end{array}$ & $\begin{array}{l}-0.056^{* *} \\
(0.020)\end{array}$ & $\begin{array}{l}-0.044 * * \\
(0.017)\end{array}$ & $\begin{array}{l}-0.057 * \\
(0.025)\end{array}$ \\
\hline Recent Hire & $\begin{array}{l}-0.034 * \\
(0.016)\end{array}$ & $\begin{array}{l}-0.001 \\
(0.011)\end{array}$ & $\begin{array}{l}-0.009 \\
(0.022)\end{array}$ & $\begin{array}{c}0.012 \\
(0.023)\end{array}$ \\
\hline $\mathrm{R}^{2}$-within & 0.333 & 0.101 & 0.424 & 0.110 \\
\hline $\mathrm{N}$ (worker-years) & $2,475,478$ & $2,475,478$ & 395,053 & 395,053 \\
\hline
\end{tabular}

Notes: The table shows the estimated acquisition effect for a reference group and the estimated foreign wage returns to individual characteristics relative to the reference group. Reference group: male with elementary education and 11-20 years of potential labor market experience, not recent hires. Results are derived from an extension of Equation (2) using the LEED where the acquisition dummy is interacted with individual characteristics. All regressions include divestment period, year and region effects (the latter pertain to establishments so are not collinear with FFE). The FFE specification also includes gender, education, experience, and their interactions, as in column (2) of Table 5. ** = significant at 0.01 . 


\begin{tabular}{|c|c|c|c|c|}
\hline \multirow[b]{2}{*}{ Foreign interactions } & \multicolumn{2}{|c|}{ Full Sample } & \multicolumn{2}{|c|}{ Matched Sample } \\
\hline & FFE & WGFE & FFE & WGFE \\
\hline Manager & $\begin{array}{l}0.478 * * \\
(0.045)\end{array}$ & $\begin{array}{l}0.328 * * \\
(0.050)\end{array}$ & $\begin{array}{l}0.216^{* *} \\
(0.046)\end{array}$ & $\begin{array}{l}0.195 * * \\
(0.044)\end{array}$ \\
\hline Professional & $\begin{array}{c}0.361 * * \\
(0.043)\end{array}$ & $\begin{array}{l}0.240 * * \\
(0.033)\end{array}$ & $\begin{array}{l}0.277^{* *} \\
(0.046)\end{array}$ & $\begin{array}{l}0.245^{* *} \\
(0.034)\end{array}$ \\
\hline Associate Professional & $\begin{array}{c}0.163 * * \\
(0.022)\end{array}$ & $\begin{array}{l}0.143^{* *} \\
(0.022)\end{array}$ & $\begin{array}{l}0.168 * * \\
(0.044)\end{array}$ & $\begin{array}{c}0.155^{* *} \\
(0.036)\end{array}$ \\
\hline Skilled non-manual & $\begin{array}{l}0.122 * * \\
(0.022)\end{array}$ & $\begin{array}{l}0.092^{* *} \\
(0.020)\end{array}$ & $\begin{array}{l}0.110 * * \\
(0.023)\end{array}$ & $\begin{array}{c}0.091 * * \\
(0.025)\end{array}$ \\
\hline Service & $\begin{array}{c}0.088 \\
(0.059)\end{array}$ & $\begin{array}{c}0.073 \\
(0.065)\end{array}$ & $\begin{array}{c}0.116 \\
(0.062)\end{array}$ & $\begin{array}{c}0.130 \\
(0.069)\end{array}$ \\
\hline Skilled manual & $\begin{array}{l}0.121 * * \\
(0.020)\end{array}$ & $\begin{array}{l}0.122 * * \\
(0.021)\end{array}$ & $\begin{array}{l}0.090 * * \\
(0.021)\end{array}$ & $\begin{array}{l}0.090 * * \\
(0.029)\end{array}$ \\
\hline Unskilled & $\begin{array}{l}0.123 * * \\
(0.023)\end{array}$ & $\begin{array}{l}0.158^{* *} \\
(0.030)\end{array}$ & $\begin{array}{l}0.105^{* *} \\
(0.026)\end{array}$ & $\begin{array}{c}0.108 * * \\
(0.034)\end{array}$ \\
\hline $\mathrm{R}^{2}$-within & 0.327 & 0.201 & 0.432 & 0.243 \\
\hline N (worker-years) & $2,475,478$ & $2,475,478$ & 395,053 & 395,053 \\
\hline
\end{tabular}

Notes: The table shows the estimated acquisition effects for the listed occupational groups using the LEED samples. Coefficients and standard errors from an extension of Equation (2) where the foreign dummy is interacted with occupational group dummies. All regressions include divestment period, year and region effects (regions pertain to establishments so are not collinear with FFE). The FFE specification also includes gender, education, experience, and their interactions, as in column (2) of Table 5. ** = significant at 0.01 . 
Table 10: Estimated FDI Effects on Wages of Incumbent and Non-Incumbent Workers

\begin{tabular}{ccccc}
\hline Foreign interactions & FFE & WGFE & WFE & $\begin{array}{c}\text { WFE } \\
\text { restricted }\end{array}$ \\
\hline Full Sample & & & & \\
\hline Non-incumbent & $0.186^{* *}$ & $0.158^{* *}$ & --- & --- \\
& $(0.021)$ & $(0.022)$ & & \\
Incumbent & $0.149^{* *}$ & $0.120^{* *}$ & $0.057^{* *}$ & $0.067^{* *}$ \\
& $(0.015)$ & $(0.018)$ & $(0.014)$ & $(0.017)$ \\
\hline $\mathrm{R}^{2}$-within & 0.340 & 0.097 & 0.088 & 0.088 \\
\hline $\mathrm{N}$ (worker-years) & $2,475,478$ & $2,475,478$ & $2,475,478$ & $2,449,923$ \\
\hline Matched Sample & & & & \\
\hline Non-incumbent & $0.153^{* *}$ & $0.154^{* *}$ & --- & --- \\
& $(0.026)$ & $(0.032)$ & & \\
Incumbent & $0.064^{* *}$ & $0.063^{* *}$ & $0.036^{*}$ & $0.041^{*}$ \\
& $(0.021)$ & $(0.024)$ & $(0.017)$ & $(0.019)$ \\
\hline $\mathrm{R}^{2}$-within & 0.434 & 0.106 & 0.125 & 0.133 \\
\hline $\mathrm{N}$ (worker-years) & 395,053 & 395,053 & 395,053 & 351,969 \\
\hline
\end{tabular}

Notes: These estimates result from an extension of Equation (2) using the LEED that permits the foreign effect to vary between incumbents and non-incumbents. Incumbents defined as workers followed over time with at least one wage observation in the pre-acquisition period and at least one observation post-acquisition. FFE = firm fixed effects; WGFE = worker-group fixed effects; WFE = individual worker fixed effects. All regressions include divestment period, year, and region effects (the latter pertain to establishments so are not collinear with FFE). The FFE specification also includes gender, education, experience, and their interactions, as in column (2) of Table 5. The final column "WFE restricted" includes only those workers with at least two post-acquisition observations. $* *=$ significant at $0.01 ; *$ significant at 0.05 . 
Table 11: Estimated FDI Effects on Hiring and Separation

\begin{tabular}{|c|c|c|c|c|}
\hline & FFE & WGFE & FFE & WGFE \\
\hline \multicolumn{5}{|l|}{ Hiring } \\
\hline Foreign & $\begin{array}{l}-0.000 \\
(0.013)\end{array}$ & $\begin{array}{l}-0.014 \\
(0.014)\end{array}$ & $\begin{array}{l}-0.000 \\
(0.017)\end{array}$ & $\begin{array}{l}-0.011 \\
(0.021)\end{array}$ \\
\hline Foreign*Wage & --- & --- & $\begin{array}{c}0.001 \\
(0.002)\end{array}$ & $\begin{array}{c}0.001 \\
(0.002)\end{array}$ \\
\hline $\mathrm{R}^{2}$-within & 0.060 & 0.003 & 0.063 & 0.007 \\
\hline N (worker-years) & 366,832 & 366,832 & 366,832 & 366,832 \\
\hline \multicolumn{5}{|l|}{ Separation } \\
\hline Foreign & $\begin{array}{c}0.010 \\
(0.029)\end{array}$ & $\begin{array}{c}0.001 \\
(0.034)\end{array}$ & $\begin{array}{c}0.021 \\
(0.041)\end{array}$ & $\begin{array}{c}0.012 \\
(0.048)\end{array}$ \\
\hline Foreign*Wage & --- & --- & $\begin{array}{l}-0.002 \\
(0.004)\end{array}$ & $\begin{array}{l}-0.001 \\
(0.005)\end{array}$ \\
\hline $\mathrm{R}^{2}$-within & 0.036 & 0.035 & 0.036 & 0.035 \\
\hline N (worker-years) & 185,575 & 185,575 & 185,575 & 185,575 \\
\hline \multicolumn{5}{|c|}{$\begin{array}{l}\text { Notes: These estimates are based on linear probability models, extensions of Equation } \\
\text { (2) using the matched LEED sample for hiring and the matched LEED sample of linked } \\
\text { workers for separations. The dependent variables in the two panels are a dummy for } \\
\text { recent hire (in the previous calendar year) and a dummy for separation (in the next year), } \\
\text { respectively. Unconditional (weighted) means are } 0.089 \text { for hiring and } 0.260 \text { for } \\
\text { separation. FFE = firm fixed effects; WGFE = worker-group fixed effects; Foreign = } 1 \\
\text { if the firm is majority foreign owned in t-1. All regressions include year, divestment } \\
\text { period, and region effects (the latter pertain to establishments so are not collinear with } \\
\text { FFE). The FFE specification also includes gender, education, experience, and their } \\
\text { interactions, as in column (2) of Table 5. The separation regressions are weighted with } \\
\text { the inverse of the probability of inclusion in the linked worker sample. Standard errors } \\
\text { (corrected for firm clustering) are shown in parentheses. The first foreign year of each } \\
\text { firm was dropped because of ambiguity on the timing of acquisition and hiring or } \\
\text { separation in that year. }\end{array}$} \\
\hline
\end{tabular}


Table 12: Estimated FDI Effects on Employment and Exit

\begin{tabular}{|c|c|c|c|c|}
\hline \multirow[b]{2}{*}{ Foreign } & \multicolumn{2}{|c|}{ Employment } & \multicolumn{2}{|c|}{ Firm Exit } \\
\hline & $\begin{array}{l}-0.015 \\
(0.057)\end{array}$ & $\begin{array}{c}0.106 \\
(0.052)\end{array}$ & $\begin{array}{c}0.007 \\
(0.005)\end{array}$ & $\begin{array}{l}-0.007 \\
(0.008)\end{array}$ \\
\hline Foreign*Wage & --- & $\begin{array}{l}-0.016 \\
(0.022) \\
\end{array}$ & --- & $\begin{array}{l}0.007 * * \\
(0.003) \\
\end{array}$ \\
\hline $\mathrm{R}^{2}$-within & 0.261 & 0.276 & 0.017 & 0.027 \\
\hline $\mathrm{N}$ (firm-years) & 44,406 & 44,406 & 15,141 & 15,141 \\
\hline \multicolumn{5}{|c|}{$\begin{array}{l}\text { Notes: These estimates for the firm-level matched sample are based on an extension } \\
\text { of Equation (1) where the dependent variable }=\ln (\mathrm{emp} \text { ) and a dummy for exit from } \\
\text { data (in the exit regressions firm fixed effects are not included). The firm exit } \\
\text { regression is a linear probability model excluding pre-acquisition years (both for } \\
\text { treated and control firms), divestitures, and } 2008 \text {. The unconditional (weighted) mean } \\
\text { exit rate is } 0.019 \text {. FFE(firm fixed effects) are included in the employment regression. } \\
\text { All regressions include year, divestment period, and region effects (the latter pertain } \\
\text { to establishments so are not collinear with FFE). Standard errors (corrected for firm } \\
\text { clustering) are shown in parentheses. } * *=\text { significant at } 0.01 \text {. }\end{array}$} \\
\hline
\end{tabular}


Table 13: Estimated FDI Effects on Worker Composition

\begin{tabular}{ccccccc}
\hline & Female & Elementary & Vocational & High school & University & Experience \\
\hline & $-0.021^{* *}$ & -0.004 & $-0.018^{*}$ & -0.023 & $0.045^{* *}$ & $-0.971^{* *}$ \\
& $(0.006)$ & $(0.011)$ & $(0.008)$ & $(0.015)$ & $(0.010)$ & $(0.299)$ \\
\hline $\mathbf{R}^{\mathbf{2}}$ & 0.001 & 0.025 & 0.002 & 0.003 & 0.014 & 0.010 \\
\hline
\end{tabular}

Notes: $\mathrm{N}=395,053$ worker-years. Estimated coefficients on the foreign acquisition dummy from separate workerlevel regressions with listed individual characteristics as dependent variables; except for experience, which is in years, all are linear probability models. Regressions include firm fixed effects, year, divestment period, and region effects. $* *=$ significant at $0.01 . *=$ significant at 0.05 . 


\section{Table 14: Estimated FDI Effects on Labor Productivity and Average Wage - Matched Firm-Level Sample}

\begin{tabular}{lcc}
\hline & $\begin{array}{c}\text { Average } \\
\text { Wage }\end{array}$ & $\begin{array}{c}\text { Labor } \\
\text { Productivity }\end{array}$ \\
\hline No controls for capital intensity & $\begin{array}{c}0.248 * * \\
\text { and material cost/worker }\end{array}$ & $\begin{array}{c}0.261 * * \\
(0.029)\end{array}$ \\
\hline $\mathrm{R}^{2}$-within & 0.403 & 0.186 \\
\hline Controls for capital intensity and & $0.199 * *$ & $0.161 * *$ \\
material cost/worker & $(0.028)$ & $(0.050)$ \\
\hline $\mathrm{R}^{2}$-within & 0.493 & 0.512 \\
\hline
\end{tabular}

Note: Coefficients on Foreign from extensions of Equation (1) with average wage and labor productivity as dependent variables and, in the lower panel, controls for capital and material cost per worker. Regressors in all specifications include firm fixed effects (FFE), year, divestment period, and region effects. $\mathrm{N}=44,094$ firm-years in the first specification and 43,081 firmyears in the second. Regressions are weighted by employment. $* *=$ significant at 0.01 . 
Table 15: Estimated FDI Effects on Wages and Productivity by Source Country GDP, Acquisition Period, and Target Type - Matched Samples

\begin{tabular}{|c|c|c|}
\hline & $\begin{array}{l}\text { Average } \\
\text { Wage }\end{array}$ & $\begin{array}{c}\text { Labor } \\
\text { Productivity }\end{array}$ \\
\hline GDP per capita & $\begin{array}{l}0.033 * * \\
(0.007)\end{array}$ & $\begin{array}{c}0.039 * \\
(0.016)\end{array}$ \\
\hline $\mathrm{R}^{2}$-within & 0.344 & 0.148 \\
\hline $\begin{array}{l}\text { Early Acquisition } \\
\text { (pre-1999) }\end{array}$ & $\begin{array}{l}0.247 * * \\
(0.037)\end{array}$ & $\begin{array}{l}0.257 * * \\
(0.088)\end{array}$ \\
\hline $\begin{array}{l}\text { Late Acquisition } \\
\text { (post-1998) }\end{array}$ & $\begin{array}{l}0.251 * * \\
(0.091)\end{array}$ & $\begin{array}{c}0.270 * \\
(0.129) \\
\end{array}$ \\
\hline $\mathrm{R}^{2}$-within & 0.403 & 0.186 \\
\hline State-Owned & $\begin{array}{l}0.310 * * \\
(0.033)\end{array}$ & $\begin{array}{l}0.326 * * \\
(0.088)\end{array}$ \\
\hline Domestic Private & $\begin{array}{l}0.104 * * \\
(0.027)\end{array}$ & $\begin{array}{c}0.106^{*} \\
(0.046)\end{array}$ \\
\hline $\mathrm{R}^{2}$-within & 0.411 & 0.189 \\
\hline
\end{tabular}

Notes: The dependent variable is the $\ln$ (average wage) in the first specification and $\ln$ (labor productivity) in the 2 nd specification. All specifications include year, divestment period, region, and firm fixed effects (FFE). GDP per capita measures the proportionate difference between the source country's and Hungarian GDP per capita, relative to Hungarian GDP per capita, with all GDP values measured in 2000 US dollars (from http://data.worldbank.org/indicator/NY.GDP.PCAP.KD). In the first panel, $\mathrm{N}=26,675$ firm-years; in the next two, $\mathrm{N}=44,094$ firm-years; samples are identical for wage and productivity regressions. $* *=$ significant at $0.01 . *$ significant at 0.05 . 
Appendices $^{19}$

Appendix A: Supplementary Tables

Table A1: Results of Propensity Score Estimation

Firm-Level Sample $\quad$ LEED

\begin{tabular}{|c|c|c|c|c|}
\hline & Mean & Coefficient & Mean & Coefficient \\
\hline Log Average Wage & 6.230 & $\begin{array}{l}-0.258 * \\
(0.119)\end{array}$ & 6.212 & $\begin{array}{c}0.237 \\
(0.281)\end{array}$ \\
\hline$(\text { Log Average Wage })^{2}$ & 39.304 & $\begin{array}{l}0.036^{* *} \\
(0.010)\end{array}$ & 39.198 & $\begin{array}{c}0.000 \\
(0.022)\end{array}$ \\
\hline Log Employment & 1.751 & $\begin{array}{l}-0.043 * * \\
(0.017)\end{array}$ & 4.046 & $\begin{array}{c}0.041 \\
(0.078)\end{array}$ \\
\hline$(\text { Log Employment })^{2}$ & 4.901 & $\begin{array}{l}0.014 * * \\
(0.003)\end{array}$ & 17.813 & $\begin{array}{c}0.008 \\
(0.008)\end{array}$ \\
\hline Wage Growth & 0.171 & $\begin{array}{l}-0.008 \\
(0.021)\end{array}$ & 0.161 & $\begin{array}{l}-0.033 \\
(0.071)\end{array}$ \\
\hline Employment Growth & 0.046 & $\begin{array}{l}0.075^{* *} \\
(0.021)\end{array}$ & 0.013 & $\begin{array}{c}0.004 \\
(0.056)\end{array}$ \\
\hline Log Labor Productivity & 8.813 & $\begin{array}{l}-0.060 \\
(0.051)\end{array}$ & 8.396 & $\begin{array}{l}-0.027 \\
(0.110)\end{array}$ \\
\hline (Log Labor Productivity) $^{2}$ & 79.198 & $\begin{array}{c}0.004 \\
(0.003)\end{array}$ & 72.177 & $\begin{array}{c}0.005 \\
(0.006)\end{array}$ \\
\hline Log Capital Intensity & 6.771 & $\begin{array}{l}-0.079 * * \\
(0.024)\end{array}$ & 6.707 & $\begin{array}{l}-0.035 \\
(0.066)\end{array}$ \\
\hline$\left(_{\text {Log Capital Intensity) }}{ }^{2}\right.$ & 48.771 & $\begin{array}{l}0.008 * * \\
(0.002)\end{array}$ & 47.362 & $\begin{array}{c}0.005 \\
(0.005)\end{array}$ \\
\hline Pseudo $\mathrm{R}^{2}$ & --- & 0.136 & --- & 0.244 \\
\hline
\end{tabular}

Note: Marginal effects from probit regressions. The sample includes treated firms in the acquisition year and always domestic firms. Dependent variable $=1$ for foreign firms in the acqusition year. All righthand side variables are from one year before the acquisition. Wage Growth and Employment Growth = growth rates from two years before acquisition to one year before acquisition. The regressions are pooled, and control firms are weighted so that their weighted number matches the number of treatments each year. Industry and year effects added. $\mathrm{N}=691,243$ for the firm-level sample, 81,639 for the LEED. ** $=$ significant at $0.01 ; *=$ significant at 0.05 .

\footnotetext{
${ }^{19}$ Appendix B, which contains a fuller description of the data, is available on request from the authors.
} 
Table A2: Balance of Covariates in the Matched Sample, One Year Before Acquisition

\begin{tabular}{lcc}
\hline & \multicolumn{2}{c}{$\begin{array}{c}\text { Normalized Difference } \\
\text { Treated - Controls }\end{array}$} \\
\cline { 2 - 3 } & $\begin{array}{c}\text { Firm-Level } \\
\text { Sample }\end{array}$ & LEED \\
\hline Average Earnings & 0.003 & 0.024 \\
Employment & 0.019 & 0.006 \\
Wage Growth & 0.025 & -0.019 \\
Employment Growth & 0.003 & 0.023 \\
Capital Intensity & 0.013 & 0.005 \\
Labor Productivity & 0.007 & 0.014 \\
\hline $\begin{array}{l}\text { Notes: Difference in average values between treated and control firms, } \\
\text { scaled by the square root of the sum of variances. Mean of control } \\
\text { observations subtracted from mean of treated observations. Differences } \\
\text { computed one year before acquisition. }\end{array}$
\end{tabular}


Table A3: The Effect of Foreign Ownership on Working Hours - LEED, 1999-2008

\begin{tabular}{lcc}
\hline & FFE & WGFE \\
\hline Full Sample & & \\
Acquisition Effect & 0.003 & -0.007 \\
& $(0.008)$ & $(0.008)$ \\
$\mathrm{R}^{2}$ & 0.296 & 0.290 \\
\hline Matched Sample & & \\
Acquisition Effect & -0.006 & $-0.017 *$ \\
& $(0.009)$ & $(0.007)$ \\
$\mathrm{R}^{2}$ & 0.325 & 0.344 \\
\hline
\end{tabular}

Notes: $\mathrm{N}=999,550$ for the full, and $\mathrm{N}=169,010$ for the matched sample. The dependent variable is the log of monthly paid hours. 
Table A4: Wage Underreporting and Foreign Acquisition

\begin{tabular}{lcccc}
\hline & FFE & WGFE & $\begin{array}{c}\text { Matching } \\
\text { with FFE }\end{array}$ & $\begin{array}{c}\text { Matching } \\
\text { with WGFE }\end{array}$ \\
\hline Firm sample & & & \\
\hline $\begin{array}{l}\text { Interactions with Cheating } \\
\text { Industry }\end{array}$ & & & \\
$\quad$ Acquisition & $0.191^{* *}$ & - & $0.147^{* *}$ & - \\
& $(0.035)$ & & $(0.046)$ & \\
Acquisition * Non- & $0.112^{* *}$ & - & $0.116^{*}$ & - \\
Cheating Industry & $(0.041)$ & & $(0.054)$ & \\
\hline
\end{tabular}

\section{LEED sample}

\section{Interactions with Cheating}

Industry

Acquisition

$0.132 * *$

(0.024)

$0.124 * *$

(0.026)

$0.087 * *$

(0.028)

$0.111^{* *}$

0.049

0.024

0.049

(0.037)

Acquisition * Non-

(0.026)

$(0.028)$

(0.029)

0.020

Cheating Industry

$(0.026)$

Proportion of Workers at

Minimum Wage

Acquisition

$-0.067 * *$
$(0.011)$

$-0.057 * *$

$-0.041 * *$

$-0.042 * *$

(0.012)

(0.007)

(0.009)

Notes: In the top panels, the foreign acquisition dummy is interacted with a dummy variable that equals one for companies operating in two-digit industries with a low wage misreporting index computed by Elek et al. (2009). In the bottom panel, we run a linear probability regression where the dependent variable is an indicator for earnings less than 1.03 times the legal minimum wage. FFE, WGFE and included covariates are the same as in Table 13. $\mathrm{N}=1,881,267$ for the full firm sample, and $\mathrm{N}=44,406$ for the matched firm sample. $\mathrm{N}=2,475,478$ for the full LEED sample, and $\mathrm{N}=395,053$ for the matched LEED sample. 